University of St. Thomas, Minnesota

UST Research Online

2013

\title{
Underwriters and the Broken Chinese Wall: Institutional Holdings and Post-IPO Securities Litigation
}

Sergey Sergeevich Barabanov

University of St. Thomas, Minnesota, ssbarabanov@stthomas.edu

Onem Ozocak

Brock University, oozocak@brock.ca

Thomas Walker

Concordia University, Montreal, Quebec, Canada

Follow this and additional works at: https://ir.stthomas.edu/ocbfincpub

Part of the Finance and Financial Management Commons

This Article is brought to you for free and open access by the Finance at UST Research Online. It has been accepted for inclusion in Finance Faculty Publications by an authorized administrator of UST Research Online. For more information, please contact asle4660@stthomas.edu. 


\title{
UNDERWRITERS AND THE BROKEN CHINESE WALL: INSTITUTIONAL HOLDINGS AND POST-IPO SECURITIES LITIGATION
}

\author{
Sergey S. Barabanov \\ University of St. Thomas \\ Onem Ozocak \\ Brock University \\ Kuntara Pukthuanthong \\ San Diego State University \\ Thomas J. Walker \\ Concordia University
}

\begin{abstract}
We examine whether underwriters have an information advantage over other institutional investors in new public companies. Focusing on firms targeted by IPO-related class action litigation and a matched sample of nonsued firms, we find evidence suggesting that lead underwriters retain an information advantage in the firms they take public and that they capitalize on this information by closing out or reducing their holdings in sued firms prior to the eventual litigation date. An examination of analyst opinions suggests that analysts affiliated with lead underwriters are reluctant to reduce their earnings forecasts or downgrade sued firms before the litigation date.
\end{abstract}

JEL Classification: G11, G12, G14, G18, K22

\section{Introduction}

The primary goal of this study is to examine whether underwriters retain an information advantage in firms they take public and whether they capitalize on their superior knowledge better than other institutions. We distinguish between money managers affiliated with lead underwriters, managers affiliated with other members of the underwriting syndicate, and unaffiliated institutional investors, and examine their relative abilities to anticipate negative developments in new public companies at an early stage and whether and to what extent they decrease positions in such firms over time.

To answer our research questions we investigate initial levels as well as changes in lead underwriter, syndicate member, and unaffiliated institutional ownership around

We are thankful to colleagues at Concordia University, the University of St. Thomas, the University of Mannheim, UCLA, Rutgers University, and Washington State University for helpful comments. Sergey Barabanov gratefully acknowledges support from the Opus College of Business, University of St. Thomas. Thomas Walker gratefully acknowledges the financial assistance provided by the Canadian Social Sciences and Humanities Research Council (SSHRC) and Germany's Alexander von Humboldt Foundation. 
IPO-related lawsuits. In these lawsuits, investors and their law firms typically accuse the IPO firm of having omitted from or misrepresented material negative information in its IPO prospectus that would have affected the investors' decision to invest in the company. We choose litigation announcements because we hypothesize that they are not entirely unexpected for the firm itself and those parties that have an information advantage about the firm.

Institutional investors have long been considered as being more sophisticated than individuals and there is abundant empirical evidence that supports this "smart money" view of the industry. For example, there are several studies that document a positive correlation between changes in institutional ownership and returns in secondary markets (e.g., Nofsinger and Sias 1999; Barabanov and McNamara 2013; Sias, Starks, and Titman 2006). One implication of the "smart money" theory is that professional money managers are more sophisticated than individuals and are therefore more successful at avoiding poorly performing firms or at selecting winning stocks than the average individual investor. In addition to examining differences in the trading behavior of institutional and individual (retail) investors, a large body of research has investigated differences in trading patterns among different types of institutions, that is, banks, mutual funds, and so on. Yet, unlike for seasoned firms, there are few studies that examine institutional ownership trends for new public companies. Specifically, we are not aware of any studies that compare the trading of lead underwriters, syndicate members, and nonunderwriting institutions in young IPO firms. Our study attempts to close this gap.

If lead underwriters rely on the same information and employ the same analytical methods as syndicate members and other (unaffiliated) institutions, we would not expect them to be more successful than syndicate members and other institutions in the post-IPO market. However, unlike syndicate members and other institutions, lead underwriters are often personally familiar with the managers of the firms they take public and are more likely to be aware of material developments within IPO firms at the time of the IPO and thereafter. Moreover, they should be in a good position to judge management's abilities because they have personally dealt with the firm's managers over an extended period. This implies that even if all material information is properly disclosed in a firm's IPO prospectus, lead underwriters remain better positioned to understand the company's business and to correctly interpret management's ability to react to any post-IPO developments that may affect the firm. Furthermore, it is likely that during their roadshow underwriters will gain valuable insights into the concerns that other institutions have about the issuing firm and its industry, which, once aggregated, will provide them with a clearer overall picture about the investing industry's opinion about the firm. Taken together, lead underwriters are not only likely to have better access to hard information about the firms they take public but are also in a position to build up a considerable "soft information" advantage relative to other institutional investors. ${ }^{1}$ Consequently, lead underwriting firms may be able to better understand company prospects at the time of the

\footnotetext{
${ }^{1}$ The use of soft information by underwriters has been examined previously, albeit not in an IPO context. For instance, Butler (2008) finds that investment banks with a local presence are better able to assess soft information about local borrowers and place difficult municipal bond issues.
} 
IPO, better interpret firm- and industry-specific developments that affect the company after its IPO, and further enhance their information advantage by collecting and analyzing information about similar firms and sectors by underwriting IPOs or secondary offerings for other firms in the same industry. We hypothesize that these factors allow lead underwriters to not only enter the IPO aftermarket with a static information advantage that allows them to identify "at-risk" companies early on but that they also dynamically enhance their information advantage over time. Based on this premise, our first hypothesis (Hypothesis 1a) proposes that lead underwriters decrease their holdings in sued IPOs (with which they are associated) during quarters $T-2$ and $T-1$, where quarter $T$ includes the lawsuit announcement date. Similarly, we hypothesize that nonlead members of the underwriting syndicate and other (unaffiliated) institutions do not significantly decrease their holdings in sued IPOs during quarters $T-2$ and $T-1$, where quarter $T$ includes the lawsuit announcement date (Hypothesis 1b).

We find support for prior anecdotal evidence about net institutional selling in recent IPOs as first empirically documented by Field and Lowry (2004). Furthermore, our findings reveal that institutional owners sell their positions sooner and to a greater extent in IPOs that are subject to subsequent class action litigation than in nonsued IPOs. Most important, we document that lead underwriters are more proactive than unaffiliated institutions in selling shares of IPO firms that are later sued. Nonlead members of the syndicate do not exhibit any significant abilities in identifying potential litigation targets and in avoiding ownership in these firms. Unlike institutions that were not part of the underwriting syndicate, lead underwriters appear to capitalize on their information advantage at least one more time when they start acquiring back positions in recent IPOs shortly after the litigation is announced. All of our findings are consistent with institutions in general and lead underwriters in particular being well-informed investors, who are actively trading on their information advantage. In addition, we hypothesize that the trading behavior of lead underwriters before the litigation announcement is positively related to the abnormal returns of sued firms, particularly if they are able to predict lawsuits that hit the market by surprise. Thus, our second hypothesis (Hypothesis 2a) proposes that lead underwriters have superior information and are able to reduce their stock holdings during the period $T-4$ to $T-1$ in firms that are sued by surprise, that is, in firms that experience significant negative cumulative abnormal returns (CARs) around the lawsuit announcement date. In the same vein, we argue that nonlead members of the underwriting syndicate and unaffiliated institutions do not have superior information and are not able to reduce their holdings before unexpected lawsuits (Hypothesis 2b).

Our results show that lead underwriters' stock holding changes from $T-4$ to $T-1$ are positively related to the CARs of sued firms during a $(-1,1)$ event window around the announcement date, suggesting they are able to identify potential litigation targets better than other market participants.

Furthermore, we explore whether an institution's trading decisions conform to the earnings forecasts provided by its analysts. In our final hypothesis (Hypothesis 3 ) we argue that lead underwriter-affiliated analysts adjust their earnings forecasts downward before the lawsuit announcement to a lesser extent than analysts affiliated with nonlead members of the underwriting syndicate and other (unaffiliated) institutions. 
Although most institutions show a tendency to make large downward revisions in their earnings forecasts before a lawsuit, we find evidence that suggests that lead underwriter-affiliated analysts make considerably smaller such revisions for sued firms before the litigation date, even though lead underwriters and lead underwriter-affiliated money managers significantly reduce their positions during that time. For uninformed investors who blindly incorporate these observable trends in earnings forecasts into their trading decisions, this finding is disconcerting as it suggests a discrepancy between what lead underwriters say and do, that is, an inconsistency in the behavior of their in-house analysts and affiliated money managers. The trading patterns of nonlead members of the underwriting syndicate and other (unaffiliated) institutions are generally more in line with the earnings forecasts provided by their analysts.

Our results of lead underwriters' informational advantage are in line with prior findings in the literature. For instance, Rowley and Baum (2008) examine 40 years of IPO data and show that lead underwriters derive an information advantage from having a better ability to network. By possessing this unique quality, lead underwriters can select any nonlead underwriters. On the other hand, nonlead managers have restricted abilities to improve their network and can only accept or reject offers presented to them but cannot initiate or choose other nonlead underwriters. All in all, Rowley and Baum show that lead underwriters are better able to use and improve upon their network position than nonlead underwriters.

Furthermore, Dechow, Hutton, and Sloan (2000) and Corwin and Schultz (2005) provide evidence suggesting that lead underwriters have both an information advantage and full control of the going-public process whereas nonlead underwriters play at best a subordinate role. They argue that lead underwriters perform a variety of crucial tasks that arise when a company plans to go public (e.g., bookbuilding, marketing the issue, networking, consulting, assisting with exchange listing, etc.). The competition among investment banks to become one of the lead underwriters for an issue can often be fierce for the largest and most desirable IPOs, as underwriters vie for top positions in underwriter rankings and seek higher fees associated with a lead position. Lead underwriters also have control over and can limit the number of co-managers to avoid competition during the IPO process. Nonlead underwriters have less work and are usually cheap to include. Overall, Corwin and Schultz conclude that lead underwriters have sole power to determine the offer price for an issue and can essentially ignore nonlead underwriters.

A growing body of literature examines the dual nature of underwriting and market-making activities by investment banks. Ellis, Michaely, and O'Hara (2000), for example, document an information advantage for lead underwriters by showing that lead underwriters are dominant market makers and that they generate positive trading profits that are increasing in the level of underpricing. Moreover, Ellis, Michaely, and O'Hara note that after the market closes on the day before the issuance date, the firm and the lead underwriter meet to discuss the final offer price and the exact number of shares to be sold. Nonlead underwriters do not play a vital role in this or any other pricing decisions.

A recent example that demonstrates the information advantage and sole control by lead underwriters is Facebook. Morgan Stanley was one of the lead underwriters for Facebook's May 18, 2012, IPO. A June 18, 2012, Wall Street Journal article notes: 
Morgan Stanley hosted all major group presentations on the "roadshow" to pitch big investors. As the tour began, a banker on the underwriting team not at Morgan Stanley asked a Facebook executive whether his firm would attend the investor meetings. The banker recalls that the executive told him no, that Morgan Stanley wants to control the message. Morgan Stanley emailed other lead underwriters its schedule of meetings the next day with big investors, including Fidelity Investments and Putnam Investments in Boston and T. Rowe Price in Baltimore. The other bankers weren't invited to the meetings. ${ }^{2}$

Facebook's IPO illustrates how important lead underwriters are in the IPO process while nonlead underwriters usually are trivial players.

Our article is related to Barabanov et al. (2008) who examine differences in the trading behavior of different types of institutions in seasoned firms that are subject to litigation under Section 10b-5 of the 1934 Securities Exchange Act. Barabanov et al. find that institutions that are more active monitors such as mutual funds and independent investment advisors are more proactive in their trading behavior. On the other hand, institutions that are largely passive monitors, such as banks, show only a limited reaction to potential signs of impending litigation. Trading patterns by insurance firms and unclassified institutions are largely unresponsive indicators of potential litigation. Our study reveals similar institutional trading differences in a post-IPO context based on the institutions' role in the IPO underwriting process.

\section{Data}

Our data set includes information on IPOs, securities class action lawsuits, institutional ownership, analyst earnings forecasts, and secondary market returns.

\section{Initial Public Offerings}

Our IPO sample is based on information provided by the SDC Platinum New Issues database and considers IPOs filed between January 1990 and December 2003. We exclude American Depositary Receipts, reverse leveraged buyouts, spinoffs, IPOs by financial firms, limited partnerships, real estate investment trusts, closed-end funds, unit offerings, and issues with offering prices below \$5 from our IPO sample. For each IPO, we use the SDC database to identify the lead and co-lead underwriter(s) as well as the remaining members of the underwriting syndicate. ${ }^{3}$ Daily adjusted prices and returns as well as market capitalization data are obtained from the Center for Research in Security Prices (CRSP). Firms that we cannot identify on CRSP or for which CRSP data are incomplete or missing are excluded from our analysis. As a further restriction, we only consider NASDAQ-listed firms in our study. Because over $92 \%$ of all IPOs during our

\footnotetext{
${ }^{2}$ For details, see “Morgan Stanley Was 'Driver' on Facebook's Wild IPO Ride,” Technology Section, Online Wall Street Journal, June 18, 2012.

${ }^{3}$ For expositional convenience, we hereafter refer to a single lead underwriter even if co-lead underwriters exist. In cases in which there is more than one lead underwriter, any subsequent calculations are based on an average of the lead underwriters.
} 
sample period started trading on the NASDAQ, this restriction is less stringent than it may initially appear and allows us to avoid any possible intermarket differences from listing requirements to trade execution and processing. ${ }^{4}$ The resulting data set includes information on 4,283 IPOs.

\section{Securities Class Action Lawsuits}

We match our IPO sample with a litigation data set based on information provided by Stanford's Securities Class Action Clearinghouse (http://securities.stanford.edu); the Securities Class Action Alert, a monthly newsletter published by the Securities Class Action Services Division of Institutional Shareholder Services (ISS); and the Department of Justice Public Access to Court Electronic Records (PACER) database. Consistent with Lowry and Shu (2002), Zhu (2009), and Walker et al. (2012), we limit our sample by only considering lawsuits filed under Section 11 of the 1933 Securities Act within three years of an IPO. In addition, to avoid a contamination of our findings by post-IPO price support activities (see, e.g., Aggarwal 2000; Fishe 2002) or insider sales restrictions, we exclude IPOs that were sued during the initial six-month lockup period. This restriction, together with the requirement that we must have at least two quarters after the lockup period but before the litigation date during which we can measure institutional ownership changes, effectively restricts our litigation data set to lawsuits that were filed between one year and three years after an IPO. Our litigation data set thus covers January 1991 to December 2006. During that period, we identify 488 lawsuits that were filed against issuers in connection with their IPO. This number includes 297 "laddering" cases that were brought against IPO underwriters by the Securities and Exchange Commission (SEC). Because of their inherently different nature, we exclude all laddering cases from our sample. ${ }^{5}$ The remaining sample thus consists of 191 firms that went public between 1990 and 2003 and were sued in connection with misrepresentations or omissions of material information from their IPO prospectuses between 1991 and 2006. Out of these, 125 firms were sued between one and three years after their IPO.

\section{Institutional Ownership Data}

Information on institutional ownership is obtained from the CDA Spectrum database, which contains detailed information on institutional $13 \mathrm{~F}$ filings with the SEC and is currently maintained by Thomson Financial (previously CDA Investment Technologies), a part of Thomson Corporation. The database provides consolidated stock holdings for all

\footnotetext{
${ }^{4}$ To ensure that our results are not exchange specific, we perform a robustness test in which we include IPOs from all exchanges. Our results are qualitatively and quantitatively similar for this extended sample.

${ }^{5}$ In these lawsuits, plaintiffs contend that the underwriters engaged in illegal tactics by soliciting and receiving kickbacks in exchange for allocations of portions of a company's IPO, required tie-in purchases creating an artificial demand for the stock, and artificially inflated the price of the stock through "laddering" (requiring purchases of additional stock in the aftermarket at escalating prices). Issuing firms are only named as co-defendants in each of the 297 laddering cases, while underwriters are named as lead defendants. These complaints generally do not allege that an issuer engaged in any wrongdoing and are therefore distinguishable from the large majority of lawsuits otherwise represented in our data set (see Hao 2007 for additional details).
} 
institutional managers filing $13 \mathrm{~F}$ reports with the SEC. ${ }^{6}$ Our data set includes 66 quarters of recorded ownership data starting with September 1990 and ending in December 2006. ${ }^{7}$ We calculate the proportion of shares outstanding held by all institutional owners as:

$$
\% \text { Institutional Ownership }=\sum_{i=1}^{N} s_{i} / S,
$$

where $N$ is the number of institutional managers reporting their positions on form $13 \mathrm{~F}, s_{i}$ is the number of shares owned by institutional manager $i$, and $S$ is the total number of shares outstanding. We also identify institutional investors associated with investment banking firms.

To ensure the reliability of our results, it is important to correctly identify the affiliation of money managers and analysts with different investment banks. Determining these affiliations is a tedious process. We first manually determine any affiliations by using $13 \mathrm{~F}$ holdings. We further use the CDA/Spectrum Mutual Funds Holdings database, usually referred to as the Spectrum $1 \& 2$ database, to confirm the reported holdings for affiliated mutual funds in each IPO firm. The Spectrum $1 \& 2$ database includes mutual fund filings with the SEC and information for an additional 30,000 global funds. The database reports holdings for each stock at the fund level. We exclude mutual funds with reported assets of less than $\$ 1$ million under management at the time of reporting. Note that the underwriter lockup period typically does not apply to affiliated money managers. However, we did not find significant evidence that affiliated money managers reduce their positions during the lockup period of IPO firms that are sued within 6 to 12 months after the IPO. This result implies that the information advantage enjoyed by lead underwriters is not necessarily transferred to their affiliated money managers during the lockup period.

In a second step, we use the CUSIP for each IPO firm to match reported institutional holdings with our IPO sample. Because the actual allocations are not publicly available, we proxy for the initial IPO allocations by examining the first reported holdings within six months of the offer date for each IPO.

We manually identify investment-bank-affiliated mutual funds by matching the names of fund management companies with the names of investment banks, and by using a variety of sources including the Investment Company Institute, Moody's Bank and Finance Manual, Nelson's Directory of Institutional Money Managers, the Securities Industry Yearbook, and company websites. In matching the names, we presume that a prestigious investment bank would protect its brand name and only allow its affiliated funds to use it. Next, we use the above sources to supplement and confirm the affiliations we determined during the initial name match. During our sample period, there are several mergers or demergers and acquisitions among investment banks; thus, we include their predecessors, as well. For example, JP Morgan Chase is the product of series of mergers

\footnotetext{
${ }^{6}$ Note that the total proportion of institutional holdings may be slightly greater than the reported number, because only those institutions with holdings greater than $\$ 200,000$ or 10,000 shares of stock are required to report their positions on the $13 \mathrm{~F}$ form. Most institutions, however, report all of their positions.

${ }^{7}$ The September 1990 starting date is again related to the requirement that we do not consider any IPO-related lawsuits filed during the initial six-month (two-quarter) lockup period.
} 
involving JP Morgan Chase, Chemical Bank, Hambrecht \& Quist, and Manufacturers Hanover, among others. We include all of them in the data set. We also use the SDC Merger and Acquisition database and the corporate histories shown on the websites of some underwriters to make sure the identified affiliations are sensitive to mergers and acquisitions.

As to affiliated analysts, we limit our attention to the 100 institutions with the most analyst recommendations in $\mathrm{I} / \mathrm{B} / \mathrm{E} / \mathrm{S}$ to simplify the data collection process of the $\mathrm{I} / \mathrm{B} / \mathrm{E} / \mathrm{S}$ data (see also Jordan, $\mathrm{Liu}$, and $\mathrm{Wu} 2012$ ). Affiliated analysts are defined as analysts employed by lead investment banks that have IPO activities in our sample period and also have affiliations with institutional investors in Thomson Financial's CDA/ Spectrum 13f filings; that is, either there is a parent-subsidiary relation or both are subsidiaries of another institution. We then identify the lead investment bank with which an analyst is affiliated using the $\mathrm{I} / \mathrm{B} / \mathrm{E} / \mathrm{S}$ Broker Translation file.

To detect the affiliation between a lead investment bank and analysts that we could not find from the above sources, we consult Hoovers Online, the Directory of Corporate Affiliations, LexisNexis, and corporate websites.

We detect the affiliation relation between money managers and investment banks from Hoovers Online, LexisNexis, corporate websites, and the Directory of Corporate Affiliations. To identify the exact period of each relation, we check for M\&A news in LexisNexis and the Wall Street Journal. We then calculate the fraction of the shares outstanding owned by each lead underwriter and all affiliated money managers as well as the proportion of shares outstanding that is owned by other members of the underwriting syndicate and their affiliated institutions. The remainder of all institutional holdings (i.e., positions owned by institutions not affiliated with any of the underwriters) comprises holdings by other (unaffiliated) institutions.

To include positions held by all reporting branches, divisions, or sister firms affiliated with the lead underwriter or a syndicate member, we manually identify all related institutional entities that file quarterly $13 \mathrm{~F}$ forms. In calculating positions held by an underwriter we aggregate holdings reported by all related money managers. For example, an underwriter may be affiliated with independent investment advisors, mutual funds, banks, or managing trusts that are registered in different states and file separate $13 \mathrm{~F}$ forms with the SEC.

We also account for mergers when determining affiliations. For instance, if an investment bank that was the lead underwriter for an IPO merged with another bank and if a reporting money manager who is affiliated with either one of the banks reported holdings within a year of the IPO, that manager is considered an affiliated institutional investor.

We do not treat co-managers as lead underwriters because these underwriters are not book-runners, leaving the lead manager (and, in some cases, the co-lead manager) to allocate the vast majority of shares (see Chen and Ritter 2000; Cliff and Denis 2004). We further follow Cliff and Denis (2004) and identify IPOs that have joint lead managers or that have more than one underwriter that help manage the book (i.e., issues with SDC codes BM, JB, or LM). For these IPOs, we treat all lead managers as one. For instance, Credit Suisse First Boston (CSFB) acquired Donaldson Lufkin \& Jenrette (DLJ) in 2000. If DLJ served as the lead underwriter in a 1999 IPO, any holdings reported in 2000 by a CSFB-affiliated money manager would be classified as lead underwriter holdings. 
As a final step in our sample construction process, we identify for each IPO whether the lead underwriter, members of the underwriting syndicate, and/or institutional money managers associated with these institutions report holdings to the SEC on Form 13F. IPOs with no reported holdings by underwriters are excluded from our analysis (cf. Binay, Gatchev, and Pirinsky 2007). This reduces our final sample to 96 issuing firms that were sued in IPO-related securities class action lawsuits within one and three years after their issue date and had at least one underwriter that reported holdings in the firm.

Table 1 provides an overview of our IPO and litigation sample. In the first five columns we outline our sample construction process. Furthermore, in columns 6 to 8 we provide information on the eventual outcome of our sample cases as of June 2009. Because all of the securities class actions in our sample were either resolved by means of a settlement or a voluntary/involuntary dismissal rather than an actual verdict, we differentiate between cases that have been settled, cases that have been dismissed or withdrawn, and cases that are still pending in court or whose outcome is unknown. ${ }^{8}$

With few exceptions, one can observe that the litigation rate, that is, the proportion of sued IPO firms (column 3 ) relative to all IPO firms that go public in a given year (column 2) remains relatively constant at approximately $5 \%$ throughout our sample period, suggesting that about 1 of every 20 issuers eventually finds themselves the subject of an IPO related class action. As the last three columns suggest, a majority of these cases are settled, while only about one-fourth are dismissed or withdrawn.

\section{Analyst Earnings Forecasts}

When evaluating trends in analyst opinions, we use information on analyst earnings forecasts that we obtained from Thomson's I/B/E/S-Firstcall database. For each firm in our IPO sample, we calculate the mean and median analyst earnings forecast for two quarters into the future. ${ }^{9,10}$

To distinguish among different types of analysts, we follow our earlier classification scheme and separate analysts into three groups: (1) those affiliated with the lead or co-lead underwriter for the IPO, (2) those affiliated with nonlead members of the underwriting syndicate, and (3) all other analysts. As such, our approach is consistent with prior studies about IPO-related analyst recommendations such as Cliff and Denis (2004)

\footnotetext{
${ }^{8}$ Note that for consistency with our IPO sample, all lawsuit-related information in Table 1 is reported under the year in which the respective IPO firm went public, not the year in which it was sued.

${ }^{9}$ Our results are similar when we consider earnings forecasts for the quarter immediately following the lawsuit or when we consider forecasts for three or four quarters ahead. We choose earnings forecasts for two quarters into the future as the underlying data are richer than for long-term forecasts, thus providing us with the highest number of data points (comparatively fewer analysts issue long-term forecasts for recent IPOs).

${ }^{10}$ Our sample period largely precedes the reforms made by the Sarbanes-Oxley Act, signed into law by President Bush July 30, 2002. The Sarbanes-Oxley Act has altered the relations among analysts, underwriters, and the IPO firms they take public. Although it would be interesting to examine the impact of Sarbanes-Oxley on our findings, there are too few IPO-related lawsuits after this reform to draw any reliable conclusions on how it affected information asymmetries for sued IPO firms. Furthermore, Sarbanes-Oxley is not likely to affect the answer to our main question, that is, whether underwriters possess and act upon their information advantage over nonunderwriting institutional investors. Moreover, it would be interesting to explore how Regulation Fair Disclosure (Reg FD), implemented by the SEC in October 2000, affects our findings. It is likely, however, that the selective disclosure by management may have contributed considerably to the institutional information advantage we document in this study.
} 
TABLE 1. IPO Litigation-Summary Statistics.

\begin{tabular}{|c|c|c|c|c|c|c|}
\hline \multirow[b]{2}{*}{$\begin{array}{l}\text { IPO } \\
\text { Year }\end{array}$} & \multirow[b]{2}{*}{$\begin{array}{l}\text { Number } \\
\text { of IPOs }\end{array}$} & \multirow{2}{*}{$\begin{array}{c}\text { Number } \\
\text { of IPO } \\
\text { Firms Sued } \\
\text { under } \\
\text { Section } 11 \\
\text { of the } 1933 \\
\text { Securities Act }\end{array}$} & \multirow{2}{*}{$\begin{array}{c}\text { Number } \\
\text { of IPO } \\
\text { Firms Sued } \\
\text { between } \\
\text { One Year and } \\
\text { Three Years } \\
\text { After Their IPO }\end{array}$} & \multirow{2}{*}{$\begin{array}{c}\text { Number of } \\
\text { Sued IPO } \\
\text { Firms in } \\
\text { Which at } \\
\text { Least One of } \\
\text { the Underwriters } \\
\text { Held Shares }\end{array}$} & \multicolumn{2}{|c|}{ Case Outcomes } \\
\hline & & & & & Settled & $\begin{array}{l}\text { Dismissed/ } \\
\text { Withdrawn }\end{array}$ \\
\hline 1990 & 107 & 7 & 5 & 3 & 3 & 0 \\
\hline 1991 & 234 & 16 & 12 & 9 & 7 & 2 \\
\hline 1992 & 285 & 21 & 13 & 11 & 8 & 2 \\
\hline 1993 & 409 & 28 & 20 & 15 & 11 & 3 \\
\hline 1994 & 367 & 11 & 8 & 6 & 5 & 1 \\
\hline 1995 & 435 & 22 & 13 & 9 & 7 & 2 \\
\hline 1996 & 592 & 24 & 12 & 10 & 7 & 3 \\
\hline 1997 & 488 & 15 & 11 & 9 & 6 & 2 \\
\hline 1998 & 313 & 13 & 10 & 8 & 5 & 3 \\
\hline 1999 & 478 & 12 & 6 & 4 & 2 & 2 \\
\hline 2000 & 382 & 15 & 10 & 8 & 6 & 2 \\
\hline 2001 & 73 & 3 & 2 & 2 & 1 & 1 \\
\hline 2002 & 67 & 2 & 2 & 1 & 1 & 0 \\
\hline 2003 & 53 & 2 & 1 & 1 & 0 & 0 \\
\hline Total & 4,283 & 191 & 125 & 96 & 71 & 25 \\
\hline
\end{tabular}

Note: Our IPO litigation sample combines information on 4,283 new equity issues filed between January 1990 and December 2003 with data on 191 IPO-related securities class action lawsuits filed from January 1990 to December 2006 as well as information on the eventual outcome of these lawsuits as of June 2012. Our IPO data are based on information provided by the SDC Platinum New Issues database. IPOs with offer prices below \$5, unit offers, closed-end funds (including real estate investment trusts), American Depositary Receipts, reverse leveraged buyouts, limited partnerships, equity carve-outs, and foreign issues are excluded. Sued IPOs are identified by crossreferencing our IPO data set with litigation information provided by Stanford's Securities Class Action Clearinghouse (SCAC), the Securities Class Action Alert (SCAA), and the Department of Justice Public Access to Court Electronic Records (PACER) database. Laddering cases filed against the underwriters in which issuers are named as codefendants are excluded from our sample. Column 1 labels our sample period. In column 2, we list the number of IPOs per year. Column 3 lists the number of IPO firms that went public in a given year and were subsequently sued in an IPO-related lawsuit under Section 11 of the Securities Act of 1933. In column 4, we only consider lawsuits that were filed against the issuing firms within a one- to three-year period after their issue date. In column 5, we list the number of sued IPO firms for which the lead underwriter or at least one member of the underwriting syndicate or their affiliated money managers reported holdings to the Securities and Exchange Commission on Form 13F. In the last two columns, we provide information on the case outcomes against the 96 firms listed in column 5, based on information provided by SCAA and SCAC as of June 2012.

and James and Karceski (2006). Specifically, we use the I/B/E/S broker identification file to determine to what extent an issuer was covered by analysts that are affiliated with an institution in each of our three institutional categories. Just as with ownership data, we research all firms that are related to lead underwriters and to nonlead members of the underwriting syndicate. All remaining analyst data are assigned to unaffiliated institutions. Again, we account for mergers when determining affiliations. ${ }^{11}$

${ }^{11}$ Similar to Cliff and Denis (2004), we identify analyst coverage for about $93 \%$ of our sample on I/B/E/S (89 of 96 IPOs). The remaining firms are excluded from our analyst-related calculations. 


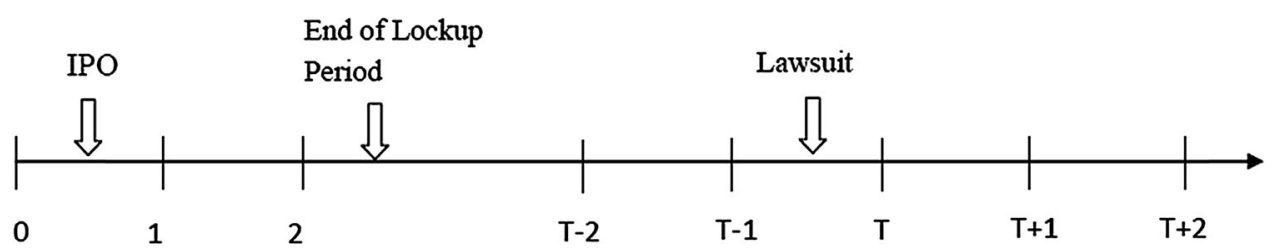

Figure I. Event Timeline.

\section{Time Period Conventions}

To ensure a convenient interpretability of our results, we define each variable used in our subsequent analysis relative to the date on which a firm is sued. Specifically, to compare institutional holdings changes (which can only be observed from quarter to quarter) with analyst earnings forecasts (which can change on a daily basis) and other variables of interest, we aggregate most of our nonquarterly data by quarter. Each quarter is then labeled relative to the quarter during which the litigation announcement occurred. The timeline in Figure I illustrates our approach. Note that IPOs and lawsuit announcements can occur at any point during a quarter. Our timeline attempts to demonstrate this fact. For expositional brevity, we henceforth refer to a quarter ending at time $t$ as quarter $t$.

We consider firms that went public during quarter 1 and were sued in quarter $T$. In fact, the IPO and lawsuit can occur at any point between the firm's IPO date and quarter $T$, respectively. As noted before, we require that the common stock of the firm has been trading for at least a year between those two dates. This accounts for the typical six-month lockup period and allows us to measure changes in institutional ownership between at least two consecutive quarters before the lawsuit announcement, that is, between times $T-2$ and $T-1 .{ }^{12}$ We also study the reaction of institutions to lawsuits both during and after the litigation quarter; that is, we measure changes in institutional ownership between times $T-1$ and $T$ and for three quarters afterward. ${ }^{13}$

\section{Matching Procedure}

Underwriters may reduce their holdings in IPO firms after the lockup period irrespective of whether they perceive the firm to be a litigation target. To control for this possibility, we perform a matched-firm analysis in which we compare changes in institutional ownership for our sample of sued IPO firms with a matched sample of nonsued IPO firms. To be included as a nonsued match, the matched firm must have had its IPO within $+/-$ six months of the sued firm, must not have been involved in any securities litigation during

\footnotetext{
${ }^{12}$ For firms that are sued more than 15 (18) months after their IPO we also examine institutional holdings three (four) quarters prior to the lawsuit announcement. The results remain intact.

${ }^{13}$ Note that institutional holdings changes during the litigation quarter (between $T-1$ and $T$ ) should be interpreted with caution as they reflect trades that occurred both before and after the lawsuit announcement. We address this issue in more detail in our Robustness section below.
} 
our sample period, must belong to the same industry, ${ }^{14}$ and must be similar to the sued firm with respect to size and return momentum, as measured by total return over a period from four quarters to one quarter before the lawsuit (from $T-4$ to $T-1$ ). Specifically, we follow the approach by Sibley and Burch (1979) and Antunovich and Sarkar (2006) and select a control firm for every event firm in our sample by minimizing the global distance between the two firms as follows:

$$
d_{i}=\sqrt{\frac{\left(\operatorname{Size}_{T-4, i}-\operatorname{Size}_{T-4, c}\right)^{2}}{\sigma_{S i z e, T-4}^{2}}+\frac{\left(\operatorname{Ret}_{T-4, T-1, i}-\operatorname{Ret}_{T-4, T-1, c}\right)^{2}}{\sigma_{R e t, T-4, T-1}^{2}}},
$$

where $d_{i}$ is the Euclidean distance between the event firm $i$ and control firm $c$, Size $_{T-4, i}$ and Size $_{T-4, c}$ are the market capitalizations of firm $i$ and control firm $c$ at time $T-4$, and $\operatorname{Ret}_{T-4, T-1, i}$ and $\operatorname{Ret}_{T-4, T-1, c}$ are the returns for the two firms, calculated over the threequarter period between time $T-4$ and time $T-1$. Finally, $\sigma_{\text {Size, } T-4}^{2}$ and $\sigma_{\operatorname{Ret}, T-4, T-1}^{2}$ are the cross-sectional variances of the average market values and returns, respectively.

Matching by industry controls for variations in litigation risk and institutional holdings across industrial sectors as documented, for example, by Lowry and Shu (2002), Bajaj, Mazumdar, and Sarin (2003), and Li and Masulis (2005). Matching by size controls for earlier findings by Alexander (1991), Zhu (2009), and Walker et al. (2012) that suggest that plaintiffs and their law firms preferentially target so-called "deep pocket" defendants, that is, large firms that are likely to settle for larger amounts. In addition, size matching controls for the institutional propensity to invest in higher capitalization stocks (see, e.g., Gompers and Metrick 2001; Bennett, Sias, and Starks 2003). Finally, by matching by prelitigation return momentum, we can distinguish between reductions in institutional ownership due to perceived litigation risk and institutional exit from poorly performing IPOs. Moreover, it allows us to control for the possibility that disgruntled shareholders and attorneys may resort to opportunistic class-action litigation against recent IPOs experiencing poor returns on their stocks. Thus, every sample firm has the same calendar period as its matching sued firm, operates in a similar industry, and has a similar size and return momentum in the prelitigation period. ${ }^{15,16}$

\footnotetext{
${ }^{14}$ To examine industry effects, we adopt the breakdown of Loughran and Ritter (2004) and Cliff and Denis (2004) and categorize firms as technology (tech) firms and nontech firms. Tech firms are those with the following SIC codes: 2833-2836, 3571, 3572, 3575, 3577, 3578, 3661, 3663, 3669, 3674, 3812, 3823, 3825-3827, 3829, $3841,3845,4812,4813,4899,7370-7375$, or $7377-7379$.

${ }^{15}$ Our findings are highly robust to virtually any reasonable matching procedure considered. For instance, we also considered industry matches based on two-digit Standard Industrial Classification (SIC) codes and on the industry classification by Breeden, Gibbons, and Litzenberger (1989) who identify 12 major industrial sectors of SIC codes that are selected to maximize the correlation of returns for firms in each sector. Moreover, we substituted our simultaneous size and return momentum matching approach with stricter routines in which we first match on size (considering various size brackets) and then on the closest return momentum, and vice versa. Furthermore, we considered simplified matches based on time, industry, and only one of size or momentum for the final matching variable. Finally, we matched on short-term return momentum (employing returns from $T-2$ to $T-1$ instead of returns from $T-4$ to $T-1$ ).

${ }^{16}$ The results are insensitive to controlling for three-month $(T-2$ to $T-1)$ or six-month $(T-3$ to $T-1)$ momentum, rather than nine-month momentum, before the litigation date.
} 


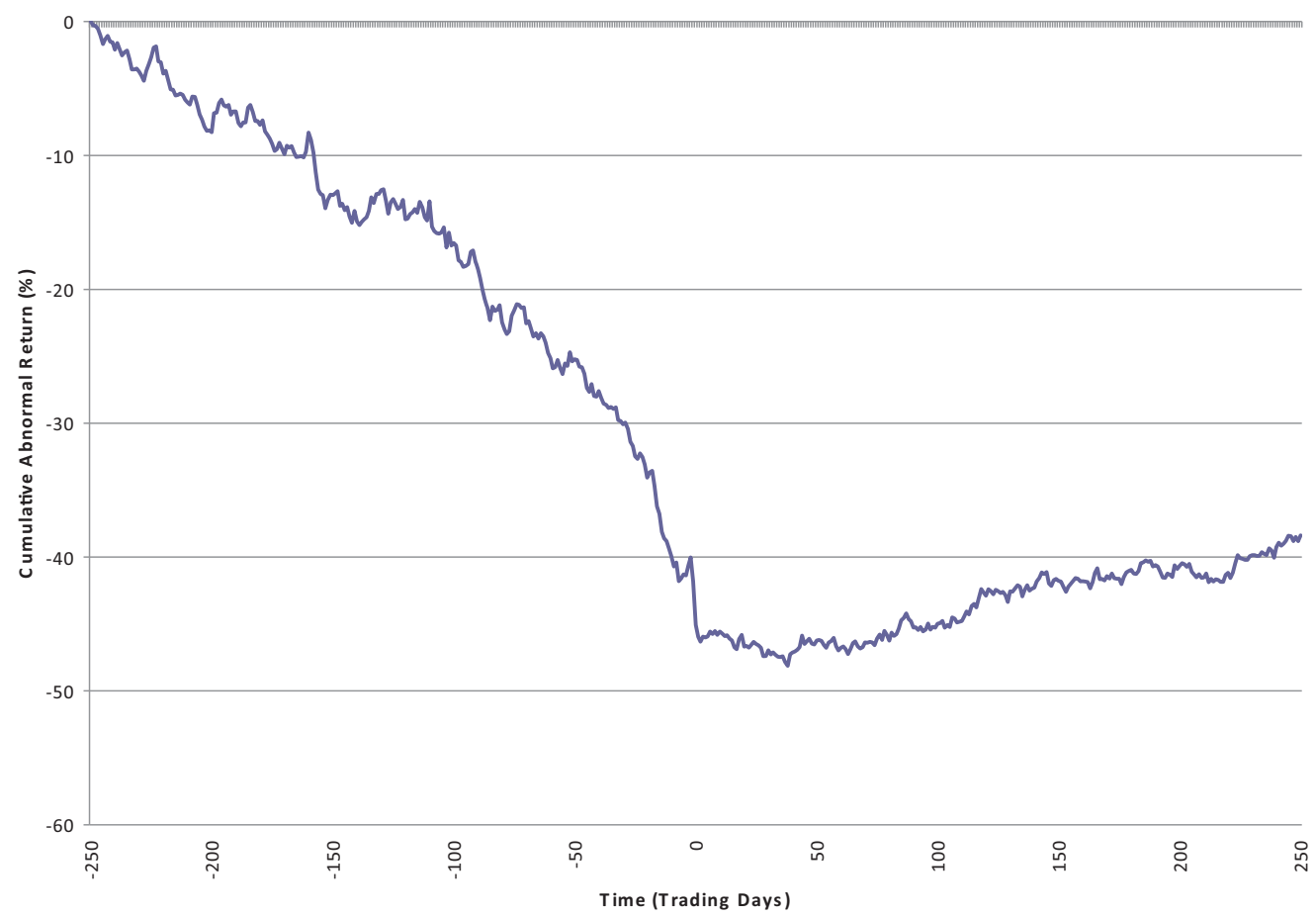

Figure II. Abnormal Stock Price Performance of Sued Firms around the Litigation Date. We plot the abnormal stock price performance of sued IPO firms around the lawsuit announcement date, denoted as day 0 . Our sample consists of 96 IPO-related securities class action lawsuits filed within one and three years after the issue date under Section 11 of the 1933 Securities Act between January 1991 and December 2006. In each of these IPOs, at least one member of the underwriting syndicate reported holdings to the Securities and Exchange Commission on Form 13F. We calculate a firm's cumulative abnormal return (CAR) following a market model approach. The firm's beta is proxied for by the average beta of all firms in the same industry (all firms with the same three-digit Standard Industrial Classification code), calculated over a three-year period ending four quarters before the lawsuit announcement. Market returns are calculated based on the Center for Research in Security Prices NYSE/ AMEX/NASDAQ value-weighted market index.

Figure II presents a time-series depiction of the abnormal stock price returns for sued firms around the litigation date. The CARs steeply decline from 250 trading days before the litigation date and then continue to decline until about 45 days after the litigation date. The CARs slightly increase until the end of our event window, that is, 250 trading days after the litigation date.

In Table 2, we present comparative statistics for sued and matched nonsued firms. We employ a series of variables that have been shown to be related to litigation risk (see, e.g., O'Brien and Bhushan 1990; Jones and Weingram 1996; Johnson, Kasznik, and Nelson 2001; Barabanov et al. 2008) and to institutional trading behavior (see, e.g., Grinblatt, Titman, and Wermers 1995; Gompers and Metrick 2001; Bennett, Sias, and Starks 2003).

We describe our sued and nonsued subsamples based on a series of firm characteristics and performance measures. Similar to Barabanov et al. (2008), we decompose the return between $T-4$ and $T-1$ (which was used as part of our matching routine) into a long- and short-term performance component, namely, $\operatorname{Ret}_{T-4, T-2}$ (which measures the 
TABLE 2. Comparative Statistics for Sued and Matched Nonsued Firms.

\begin{tabular}{|c|c|c|c|c|c|c|c|c|}
\hline \multirow[b]{3}{*}{ Variable } & \multirow{2}{*}{\multicolumn{3}{|c|}{ Sued Firms }} & \multirow{2}{*}{\multicolumn{3}{|c|}{ Nonsued Firms }} & \multicolumn{2}{|c|}{ Equality Tests } \\
\hline & & & & & & & \multirow{2}{*}{$\begin{array}{c}T \text {-Test } \\
\text { (p-value) }\end{array}$} & \multirow{2}{*}{$\begin{array}{c}\text { Wilcoxon } \\
\text { Test } \\
\text { ( } p \text {-value) }\end{array}$} \\
\hline & Mean & Median & Std. Dev. & Mean & Median & Std. Dev. & & \\
\hline Size $_{T-4}(\$$ million $)$ & 102.48 & 35.40 & 86.38 & 97.10 & 35.82 & 79.12 & .659 & .954 \\
\hline Return $_{T-4, T-2}$ & $-8.91 \%$ & $-10.44 \%$ & $42.19 \%$ & $-13.17 \%$ & $-12.74 \%$ & $49.76 \%$ & .141 & .373 \\
\hline Return $_{T-2, T-1}$ & $-12.80 \%$ & $-12.51 \%$ & $48.23 \%$ & $-7.88 \%$ & $-6.64 \%$ & $30.49 \%$ & .097 & .032 \\
\hline Return $_{T-4, T-1}$ & $-16.71 \%$ & $-17.84 \%$ & $44.09 \%$ & $-15.69 \%$ & $-15.04 \%$ & $50.12 \%$ & .378 & .341 \\
\hline Turnover $_{T-4, T-1}$ & 0.3146 & 0.2851 & 0.0310 & 0.2737 & 0.2166 & 0.0278 & .021 & .008 \\
\hline$\sigma_{T-4, T-2}$ & 0.0772 & 0.0730 & 0.0358 & 0.0501 & 0.0546 & 0.0293 & .009 & .014 \\
\hline$\Delta \sigma_{T-2, T-1}$ & 0.0052 & 0.0028 & 0.0051 & 0.0011 & 0.0003 & 0.0045 & $<.001$ & $<.001$ \\
\hline Financing Dummy & 0.17 & 0.00 & 0.38 & 0.42 & 0.00 & 0.50 & $<.001$ & $<.001$ \\
\hline$C A R(-1,1)$ & $-4.65 \%$ & $-2.08 \%$ & $18.93 \%$ & $-0.35 \%$ & $-0.29 \%$ & $1.96 \%$ & $<.001$ & $<.001$ \\
\hline
\end{tabular}

Note: We present descriptive statistics for both sued firms and matched nonsued firms. Matched firms must not have been involved in any securities litigation during our sample period, must have had their IPO within $+/-$ six months of the corresponding sued firm, must belong to the same industry as the sued firm (following the categorization of Loughran and Ritter 2004 and Cliff and Denis 2004 who distinguish between tech and nontech firms), and must have the smallest Euclidean distance relative to the sued firm in terms of both market capitalization (measured one day before the lawsuit announcement) and total return (measured from four quarters to one quarter before the lawsuit, i.e., from $T-4$ to $T-1$ ). We characterize our sample firms along several dimensions: the market capitalization at time $T-4$ converted to 1990 dollars based on Consumer Price Index (CPI) data from the Bureau of Labor Statistics $\left(\right.$ Size $\left._{T-4}\right)$, the return between time $T-4$ and $T-2\left(\right.$ Return $\left._{T-4, T-2}\right)$, the return between $T-2$ and $T-1\left(\right.$ Return $\left._{T-2, T-1}\right)$, the share turnover between $T-4$ and $T-1$ ( Turnover $_{T-4, T-1}$ ), the standard deviation of daily returns between time $T-4$ and $T-2\left(\sigma_{T-4, T-2}\right)$, the quarterly change in the standard deviation of daily returns from the quarter ending at $T-2$ to the quarter ending at $T-1\left(\Delta \sigma_{T-2, T-1}\right)$, a financing dummy that identifies whether the firm received any debt and/or equity financing between the IPO date and the litigation date (Financing Dummy), and the announcement return measured as the cumulative abnormal return during the three days surrounding the lawsuit announcement date $(C A R(-1,1))$.

return between $T-4$ and $T-2$ ), and $\operatorname{Ret}_{T-2, T-1}$ (which measures the return during the prelitigation quarter, i.e., from $T-2$ to $T-1)$. As promoted by the design of our matching routine, sued and matched nonsued firms are very close in both average and median market capitalization and in momentum returns measured from $T-4$ to $T-2$ and from $T-2$ to $T-1$. When examining short-term momentum, however, we observe that sued firms experience an accelerated decline in prices during the quarter immediately preceding litigation. The difference between the mean return of $-12.8 \%$ for sued firms and $-7.88 \%$ for the matched nonsued sample during the period $T-2$ to $T-1$ is significant at the $10 \%$ level.

In addition, we observe that in the three quarters leading up to the litigation date, sued firms experience a significantly higher prelitigation share turnover and a higher return volatility (measured as the standard deviation of daily returns) relative to nonsued firms. The return volatility of sued firms increases particularly during the last prelitigation quarter, whereas it remains comparatively stable for nonsued firms. As such, our results are similar to those of Barabanov et al. (2008) who document similar stock price developments before litigation announcements against seasoned (non-IPO) firms. When examining the post-IPO financing activities of sued and nonsued firms, we find that nonsued firms are significantly more successful in obtaining additional financing than are sued firms. Specifically, we employ a financing dummy similar to that of Johnson, Kasznik, and Nelson (2001) that identifies whether a firm received any debt and/or equity financing between the IPO date and 
the litigation date (based on information about secondary equity offerings and debt issues contained in the SDC database). Similar to Johnson, Kasznik, and Nelson who find that sued firms apply for and receive significantly less additional capital after their IPO, our results suggest that $42 \%$ of nonsued firms re-enter the capital markets during that period, while only $17 \%$ of sued firms raise additional capital. Finally, we examine the abnormal stock price performance of sued and nonsued firms during a three-day period surrounding the announcement day, that is, during a $(-1,1)$ event window.

\section{Stock Price Performance and Institutional Holdings Changes around Securities Class Action Announcements}

The extant literature shows that sued IPO firms suffer significant stock price declines during the year preceding the litigation event. ${ }^{17}$ During the subsequent year-a period characterized by many lawsuits being resolved by means of a settlement or voluntary/involuntary dismissal - sued firms tend to recover some of their losses (tests of this price recovery are weakly significant when measured, for example, over the period from one quarter to four quarters after the lawsuit announcement). ${ }^{18}$ Overall, our results suggest that lead underwriters, who naturally have superior information about the firm relative to syndicate members and other institutions, stand to profit significantly from reducing their positions before a lawsuit announcement. Considering that lead underwriters hold on average $1.44 \%$ of the shares in sued firms at time $T-4$ and given the sued firms' average market capitalization of approximately $\$ 102$ million at that time (see our analysis in Table 2), avoidance of the 3\% price drop we document on the announcement day alone would save the average lead underwriter approximately $\$ 44,000$. The savings tend to be considerably larger the earlier an institution eliminates their holdings and the larger the IPO firm, with early cash-outs from large firms frequently resulting in avoided losses in excess of $\$ 1$ million.

\section{Institutional Holdings by Type of Institution}

Institutions (and lead underwriters in particular) are likely to be better informed about the quality of a new issue than individual investors. Moreover, as suggested by Field and Lowry (2004), they remain better informed in the aftermarket. Institutional investors are well known to receive higher allocations in hot IPOs and, as is shown by Aggarwal, Prabhala, and Puri (2002), institutional allocations in underpriced issues contain additional information that is not explained by book-building and other public information.

To investigate if an institutional investor is capable of foreseeing negative developments, we examine initial levels and quarterly changes in institutional ownership before and after a lawsuit announcement.

To provide an estimate of the initial starting point for our subsequent calculations, we calculate the mean aggregate holdings in sued and nonsued firms by each of our three

\footnotetext{
${ }^{17}$ There are numerous studies that examine the stock price performance of sued firms (see, e.g., Hegde, Malone, and Finnerty 2003; Griffin, Grundfest, and Perino 2004; Chaghouri and Walker 2005; Thakor 2005; Gande and Lewis 2009; Zhu, 2009; McTier and Wald 2011; Walker et al. 2012) and they all provide similar conclusions.

${ }^{18}$ Our results remain marginally significant if we employ buy-and-hold abnormal returns, which tend to provide poorer long-term performance estimates than the returns obtained via a matched-firm analysis.
} 
groups of institutions at time $T-4$. Our results in Panel A of Table 3 suggest that lead (and to a lesser extent nonlead) underwriters enter our prelitigation period with significantly smaller holdings in sued firms than in nonsued firms. The relation is reversed for unaffiliated institutions that hold about $33.16 \%$ of the shares in a typical sued firm but only $24.69 \%$ of the shares of nonsued firms. A possible reason for these discrepancies may be that sued firms may have been "hyped up" by the firm's officers or the underwriters themselves to maximize the firm's offering proceeds even though they are aware that the firm may turn into a "fallen angel," that is, that it may not do well in aftermarket trading or that it may face other problems down the road. Moreover, our results provide some initial support for our notion that - at least from a static perspective-underwriters possess an information advantage over unaffiliated institutions that allows them to identify potential litigation targets and avoid investing in those firms early on. Panel B of Table 3 includes information on 29 IPOs with no reported underwriter holdings after the offering date. It is not surprising that once we include firms with no reported underwriter holdings in our analysis, the ownership levels of lead underwriters and syndicate members drop. It is interest, however, that the drop is particularly pronounced for sued firms and comparatively small for nonsued firms. The average stakes of lead underwriters in sued firms in which they report holdings are 1.44\% in Panel A and only $1.29 \%$ when we include firms with no reported holdings in Panel B. Similarly, syndicate holdings in sued firms with reported holdings are $1.14 \%$ but only $1.06 \%$ when we include firms with no reported holdings. In contrast, unaffiliated institutions have higher ownership in sued firms (an increase from $33.16 \%$ to $35.72 \%$ ) and nonsued firms (an increase from $24.69 \%$ to $25.28 \%$ ). In unreported results, we observe that the 29 sued firms with no reported institutional holdings have more negative CARs around the lawsuit announcement date. All in all, these results provide additional support for our hypothesis that lead underwriters have an information advantage. That is, they avoid holding shares in sued firms that have more pronounced negative returns at the very beginning.

\section{Institutional Holdings Changes by Type of Institution}

Barber and Lyon (1996) provide strong evidence that empirical tests based on changes in variables of interest, rather than on variable levels, will be better specified in most empirical contexts. For this reason, we examine changes in institutional ownership in both a univariate and multivariate context; that is, we first examine ownership changes over time and then model them in relation to various economic variables of interest. To account for initiations of new positions (i.e., a positive change from zero holdings), we measure changes in ownership from period $T-i$ to $T-j$ as the natural logarithm of $(1+$ ownership at $T-j) /(1+$ ownership at $T-i){ }^{19}$

\footnotetext{
${ }^{19}$ Note that although our estimation approach makes our results somewhat difficult to interpret economically, it aims to account for all possible ownership realizations. For example, we add one to ownership levels in the numerator and denominator to ensure that our measure is well defined for both the initiation and termination of an institution's investment in a given firm. For example, the log ratio of a $10 \%$ increase in holdings from 0.10 million to 0.11 million would be calculated as $\ln (0.11 / 0.10)=0.0953$, which is approximately equal to the actual percentage increase of $10 \%$. However, when we add 1 to the numerator and denominator, the ratio becomes $\ln (1.11$ / $1.10)=0.009049$. For expositional convenience and to achieve an approximate correspondence with the associated percentage changes, we scale the resulting figures by a factor of 1,000. For brevity, we hereafter refer to our measure as the log change in ownership.
} 


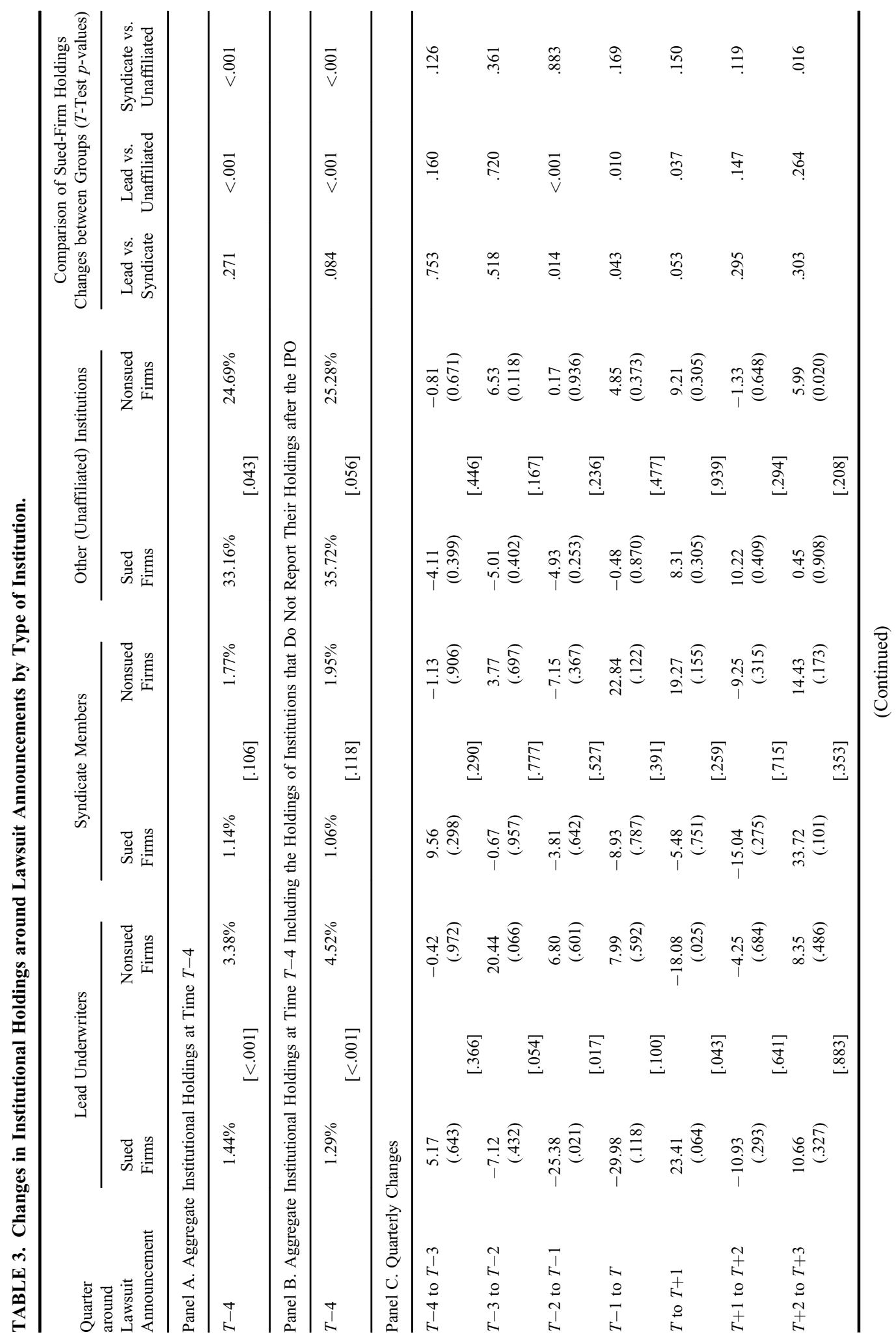




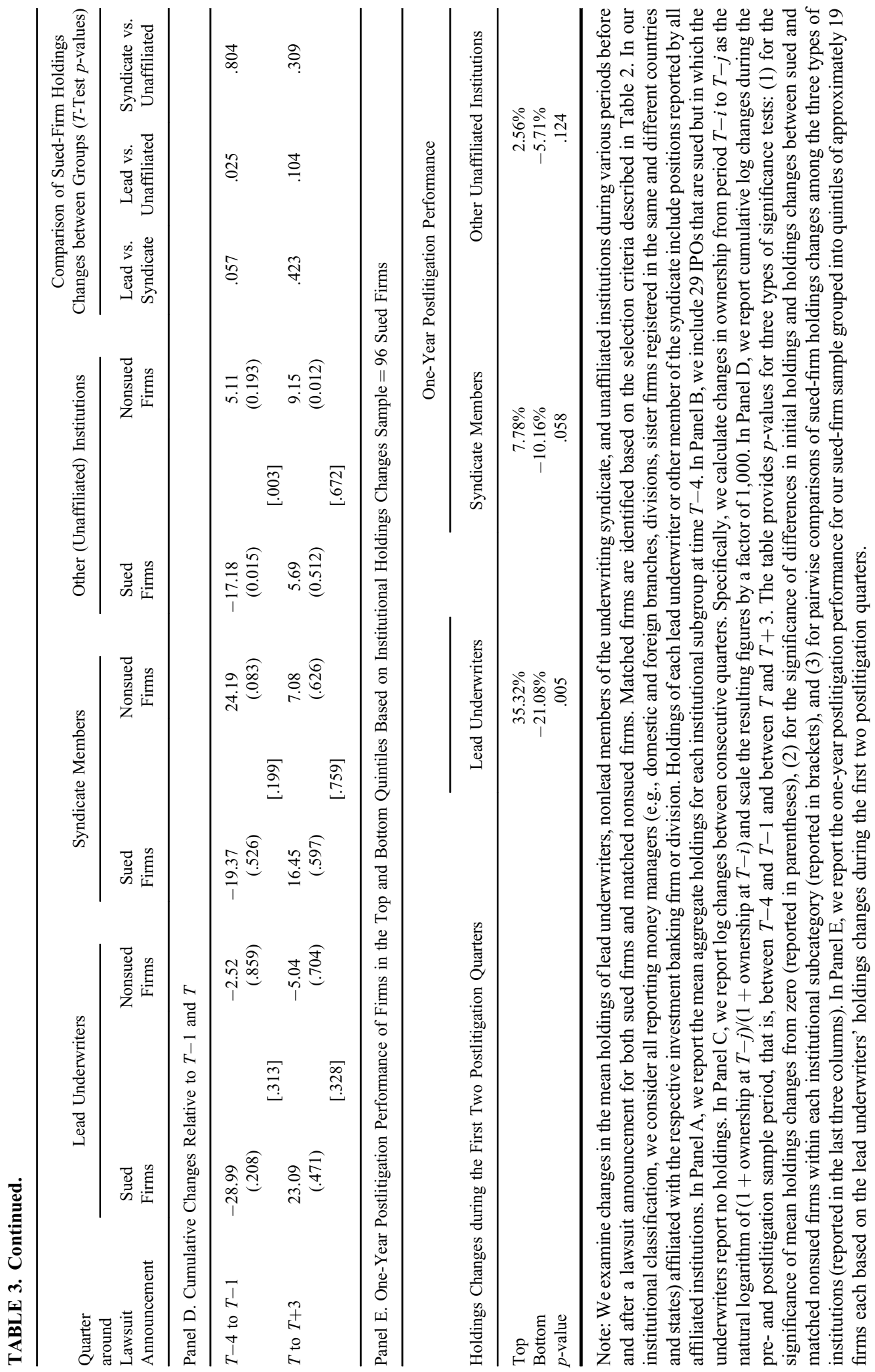


Our ownership measure has advantages over the conventional method of computing ownership changes as [ownership at $T-j-$ ownership at $T-i]$ /ownership at $T-i$. First, our measure avoids the problem of being undefined when the ownership at $T-i$ is zero. Second, our measure increases in magnitude with dollar value changes even when the conventional percentage change is constant. Hence, it captures the magnitude of dollar value changes in addition to percentage changes. Our measure and the conventional measure converge only when the underlying numbers in the calculation are large and when the actual percentage change in ownership is small. To check the consistency of our findings over both the short and long term, we also performed all of our analyses using conventional measures. The conclusions we draw from the two methodologies are highly similar. ${ }^{20} \mathrm{~A}$ decline in institutional holdings in sued firms relative to nonsued firms would suggest that institutions are able to anticipate impending lawsuits and the frequently associated negative stock price developments.

In Panels B and C of Table 3, we examine changes in mean ownership levels in sued and matched nonsued firms by the three institutional groups. Trends in median holdings changes are highly similar and are omitted here for brevity. Panel $\mathrm{C}$ reports holdings changes between consecutive quarters, and Panel D reports cumulative changes relative to the end-ofquarter holdings immediately preceding the lawsuit $(T-1)$ and following the lawsuit $(T)$. To evaluate the significance of our findings, both panels provide separate $p$-values for the significance of individual holdings changes (i.e., the significance of those holdings changes from zero, reported in parentheses), the significance of differences between holdings changes in sued and nonsued firms (reported in brackets), and the significance of differences between holdings changes by different types of institutions (i.e., lead underwriters, syndicate members, and unaffiliated institutions, reported in the last three columns).

All three groups of institutional owners decrease their holdings in sued IPOs during the two quarters before the litigation (i.e., from $T-3$ to $T-2$ and from $T-2$ to $T-1$ ). During the quarter immediately preceding the litigation $(T-2$ to $T-1)$, lead underwriters sell a significant amount of their holdings in sued firms. The decrease in holdings calculated with our measure is 25.38 , which is significantly different ( $p$-value of .017) from the increase of 6.8 in average lead underwriter holdings in matched nonsued IPOs. We also observe similar (albeit less significant) differences in lead underwriter trading when examining the quarterly changes two quarters before litigation (i.e., during the period $T-3$ to $T-2$ ).

Nonlead members of the underwriting syndicate and unaffiliated institutions exhibit similar behavior during the two prelitigation quarters, yet their quarterly holdings revisions are consistently smaller than for lead underwriters. All institutions (and underwriters in particular) continue to decrease their positions during the litigation quarter.

When examining postlitigation trading activity, we can make two interesting observations. First, it appears that some underwriters and unaffiliated institutions reacquire shares after the litigation announcement. Second, lead underwriters show a tendency to unload some of their holdings in matched nonsued firms. For example, once the lawsuit has been announced, lead underwriter positions in sued firms increase by 23.41 (mean log change from $T$ to $T+1$ ), whereas they fall significantly in matching

\footnotetext{
${ }^{20}$ The results are available upon request.
} 
nonsued firms (18.08 log decrease in the mean). These changes in mean ownership are significantly different from each other ( $p$-value of .043). The drop in underwriter positions for matching nonsued firms after a lawsuit announcement is consistent with a situation in which underwriters are afraid that once a firm has been sued, a similar firm in the same industry may be a future litigation target. In unreported median tests, we further find that median ownership by lead underwriters drops for both sued and nonsued firms during that period. This discrepancy between mean and median holdings changes in the postlitigation quarter suggests that the lead underwriters' reacquisition of shares in previously sued firms is selective. We address this phenomenon in more detail later.

\section{Comparison of Institutional Holdings Changes}

To examine whether some institutions are more informed than others, we perform a series of tests in which we compare holdings changes by different types of institutions. Specifically, we test for the significance of differences in sued-firm holdings changes for all possible pairwise comparisons among the three institutional categories. If lead underwriters indeed possess an information advantage relative to other institutions, we expect them to decrease their sued-firm holdings to a significantly larger extent than both nonlead underwriters and other (unaffiliated) institutions. Our results are presented in the last three columns of Table 3.

When comparing the cumulative mean log ownership changes by lead underwriters over the interval from $T-4$ to $T-1$ of -28.99 with the cumulative $\log$ changes in ownership levels by nonlead underwriters $(-19.37)$ and unaffiliated institutions $(-17.18)$, for example, we find the holdings changes by lead underwriters to be significantly smaller than those of the latter two groups with $p$-values of .057 (lead vs. nonlead underwriters) and .025 (lead underwriters vs. unaffiliated institutions), respectively. Even stronger differences among the three institutional groups can be observed during the quarter immediately preceding the litigation (from $T-2$ to $T-1$ ) with comparable $p$-values of .014 and $<.001$, respectively.

Although we find no significant differences between the holdings revisions of nonlead underwriters and unaffiliated institutions, our results consistently indicate that lead underwriters engage in more informed trading before litigation announcements than the two other institutional groups. In addition to our earlier results that suggest that lead underwriters possess a static information advantage as early as at time $T-4$ (see Panel A of Table 3), this indicates that their information advantage also has a dynamic component, that is, that lead underwriters are better than other institutions at interpreting and reacting to potential developments that may increase a firm's likelihood of being sued.

In summary, our results provide significant evidence for aggressive institutional selling several quarters before a litigation announcement, and they support Hypothesis 1, which suggests that lead underwriters, not nonlead underwriters and other unaffiliated institutions, are able to foresee a potential lawsuit against a firm. Moreover, lead underwriters exhibit a significantly larger variation in their holdings than other institutional investors, which supports our notion that lead underwriters indeed retain an information advantage in the firms they take public and that they reduce their positions in eventual litigation targets more aggressively than syndicate members and other institutions. In unreported results, we also find that the number of stocks lead underwriters repurchase after a lawsuit announcement is higher for dismissed cases than 
for settled cases. The results further show that lead underwriters repurchase shares before the settlement and dismissal. Overall, these results are consistent with lead underwriters' information advantage. ${ }^{21}$

\section{Postlitigation Holdings Changes and Stock Price Performance}

After the lawsuit announcement and particularly during the quarter immediately following the litigation quarter (from $T$ to $T+1$ ), lead underwriters appear to reacquire larger positions in sued firms than nonlead underwriters and unaffiliated institutions (see Panels C and D of Table 3). In unreported tests, we observe that these reacquisition activities are limited to a select few companies (median holdings decline during the same period), thus pointing to underwriters' ability to selectively and quickly react to postlitigation sell-offs. Specifically, it appears that lead underwriters reacquire large stakes in some firms while they continue to decrease their holdings in most other firms. Such a selective reacquisition of previously sold shares would be consistent with Brunnermeier and Pedersen (2005), who suggest that an investor who obtains information about an event before its public announcement can benefit from it twice: first, by trading aggressively on his or her information advantage before the public announcement, and second, by unwinding part of his or her prior trade once the information becomes public.

To shine additional light on Brunnermeier and Pedersen's (2005) argument, we examine whether lead underwriter holdings after the litigation quarter relate to a firm's postlitigation stock price performance or whether lead underwriters are able to distinguish between firms that recover well from a lawsuit and firms that continue to struggle. Specifically, we break our sued-firm sample into quintiles of approximately 19 firms each that group the firms based on the lead underwriters' holdings changes during the first two postlitigation quarters, and then we compare the one-year postlitigation performance between these groups. Our findings in Panel E of Table 3 suggest that firms in the top quintile portfolio experience an average stock price increase of about $35 \%$, whereas firms in the bottom quintile portfolio suffer an additional postlitigation stock price decline of approximately $21 \%$. The difference in holdings changes is significant with a $p$-value of .042. Similar quintile analyses in which we group firms based on the holdings changes of nonlead syndicate members and unaffiliated institutions also suggest a positive relation between holdings changes and postlitigation stock price performance. However, the performance differences are not significant at conventional levels. Overall, lead underwriters are able to distinguish between firms that recover well from a lawsuit and firms that continue to struggle.

\section{Multivariate Analysis of Ownership Changes around Class Action Litigation Announcements}

In this section, we extend our prior analysis and attempt to explain changes in institutional ownership in a multivariate framework. Specifically, we employ a merged sample that includes both the 96 firms that were sued and their 96 nonsued counterparts, and regress

\footnotetext{
${ }^{21}$ When we select matching firms based on their three- and six-month momentum, our conclusions remain qualitatively intact. Moreover, the quantitative results are even stronger than those based on nine-month returns. That is, we find that unaffiliated institutions have no information advantage while affiliated underwriters do. The results are available upon request.
} 
the change in institutional ownership in each firm by all institutions (i.e., lead underwriters, syndicate members, and unaffiliated institutions) during the prelitigation quarter (from $T-2$ to $T-1$ ) against various predetermined firm-level variables. We follow Lowry and Shu (2002), Zhu (2009), and Walker et al. (2012) and identify firms that were subject to litigation during our sample period by means of a dummy variable (Sued) that equals 1 if the firm was sued, and 0 otherwise. In addition, to examine the relative ability of each institutional subgroup to anticipate a potential lawsuit against a firm, we employ two interaction terms (Sued $*$ Lead and Sued $*$ Synd) in our estimation model. Lead is a dummy variable equal to 1 for lead underwriters; Synd is a dummy variable for syndicate members. Consistent with our hypothesis, we anticipate holdings changes by lead underwriters to be particularly responsive to signs of a potential litigation filing and thus expect the respective interaction term to be highly negative (indicating that lead underwriters make particularly large holdings revisions before lawsuits), whereas we expect less responsiveness by nonlead underwriters and unaffiliated institutions. Moreover, we employ a set of three variables that measure changes in earnings forecasts made by analysts affiliated with our three institutional groups. If institutional portfolio managers rely on the same information set as their sell-side analysts, we should find a positive relation between changes in analyst earnings forecasts and changes in IPO ownership by institutional investors. On the other hand, if underwriters provide biased forecasts - as our earlier results and the findings of Michaely and Womack (1999) and Adams (2003) suggest - we expect an insignificant (and possibly even a negative) relation between these two variables for lead (and to a lesser extent) nonlead underwriters.

Furthermore, consistent with Grinblatt, Titman, and Wermers (1995) and Barabanov et al. (2008), we seek a specification that allows for different levels of responsiveness to shorter and longer term returns before the litigation date. As our proxy for short- and long-term price momentum, we use the same variables $\left(\operatorname{Ret}_{T-2, T-1}\right.$ and $\operatorname{Ret}_{T-4, T-2}$ ) that we employed in Table 2. Finally, we proxy for the negative surprise component of a lawsuit announcement with the announcement return measured as the CAR during a three-day period surrounding the lawsuit announcement date $(C A R(-1,1))$. We employ the announcement return as an interactive variable with our Sued dummy because there is no reason to expect large abnormal returns for nonsued firms around the corresponding lawsuit announcement for sued firms. Notwithstanding our expectations about institutions' ability to partially foresee a lawsuit, we expect institutional holdings revisions to be less pronounced for firms that are sued largely by surprise, that is, firms for which the litigation announcement is associated with a large negative abnormal return. ${ }^{22}$

In addition, to account for the relative strength of a given lawsuit, that is, to what extent a case is merited, we further perform a series of regression analyses based only on our sued-firm sample in which we consider a dummy variable that differentiates between firms that settled their respective lawsuit (Settled) and firms that were sued but whose case

\footnotetext{
${ }^{22}$ Similar factors have been used in the extant institutional ownership literature (e.g., Gompers and Metrick 2001; Bennett, Sias, and Starks 2003). We choose not to include variables such as S\&P 500 membership, firm age, dividend yield, number of shares outstanding, and book value per share as they are not likely to experience significant changes during our relatively narrow sample period. Furthermore, we do not include turnover or the standard deviation of returns because they are highly correlated with our return variables.
} 
was later voluntarily withdrawn or involuntarily dismissed (see our case classifications in Table 1). The four sued firms whose cases are still pending or whose case outcome is unknown are excluded from our analysis. Because cases that are eventually settled are likely to have greater merit, their outcomes may be easier to anticipate for informed parties. We therefore expect institutional holdings changes to be particularly large before these lawsuit announcements. Himmelberg, Hubbard, and Palia (1999) suggest using firm fixed-effects to control for unobserved heterogeneity and for any firm-specific characteristics. We include these effects in all models. Furthermore, to ensure the robustness of our results and explore the marginal contribution of our different regressors, we estimate models that employ various different variable combinations. The general model that includes all variables may be specified as follows:

$$
\begin{aligned}
\Delta \text { InstOwn }_{i,(T-2, T-1)}= & \beta_{0}+\beta_{1} \text { Sued }_{i}+\beta_{2} \text { Sued }_{i} * \text { Lead }_{i}+\beta_{3} \text { Sued }_{i} * \text { Synd }_{i} \\
& +\beta_{4} \text { Settled }_{i} * \text { Lead }_{i}+\beta_{6} \text { Settled }_{i} * \text { Synd }_{i} \\
& +\beta_{7} \Delta \text { EPS }_{\text {Lead }, i,(T-2, T-1)}+\beta_{8} \Delta \text { EPS Synd }, i,(T-2, T-1) \\
& +\beta_{9} \Delta \text { EPS }_{\text {Oth }, i,(T-2, T-1)}+\beta_{10} \text { Return }_{i,(T-4, T-2)} \\
& +\beta_{11} \text { Return }_{i,(T-2, T-1)}+\beta_{12} \text { Sued }_{i} * \text { CAR }_{i,(-11)} \\
& + \text { FirmFixedEffects }_{i}+\varepsilon_{i},
\end{aligned}
$$

where $\Delta$ InstOwn $_{i,(T-2, T-1)}=\ln \left(\left(1+\right.\right.$ Owenrship $\left._{i, T-1}\right) /\left(1+\right.$ Owenrship $\left.\left._{i, T-2}\right)\right)$ for firm $i$. Sued, Lead, Synd, and Settled are dummy variables as defined earlier. $\triangle E P S_{\text {Lead }, i,(T-2, T-1)}, \Delta E P S_{\text {Synd }, i,(T-2, T-1)}$, and $\Delta E P S_{\text {Oth, },(T-2, T-1)}$ are changes in analyst earnings forecasts for firm $i$ when the analyst is affiliated with the lead underwriter, a nonlead syndicate member, or an unaffiliated institution, respectively. $C A R_{i,(-1,1)}$ is the cumulative abnormal return during days $(-1,1)$ surrounding the litigation date (day 0$)$. The model is estimated across institutions and across firms.

Models 1 to 5 of Table 4 provide our regression results for the full sample of sued and matched nonsued firms. We start our analysis with a simple model that only includes our sued dummy as an explanatory variable (model 1). Although this model suggests that on aggregate institutions have an ability to foresee an impending lawsuit, subsequent models in which we include our interaction terms Sued $*$ Lead and Sued $*$ Synd suggest this result is largely driven by the informed trading activities of lead and, to a lesser extent, nonlead members of the underwriting syndicate. Consistent with our expectations, we find that lead underwriters are most responsive to our dummy variable that identifies eventual litigation targets (with highly significant negative coefficients in all model specifications that employ the Sued $*$ Lead interaction term). Nonlead underwriters and unaffiliated institutions also exhibit some responsiveness, but the respective coefficients are economically smaller and only marginally significant in some models. As such, our multivariate analysis confirms the findings of our univariate tests in Tables 3 and 4 that suggest that lead underwriters are the most proactive of all institutions in reducing their positions before litigation announcements.

We also find evidence that suggests that institutional trades are positively aligned with analyst earnings forecasts. Particularly interesting in this context is that revisions in the opinions of affiliated analysts (i.e., analysts that are associated with lead and nonlead 


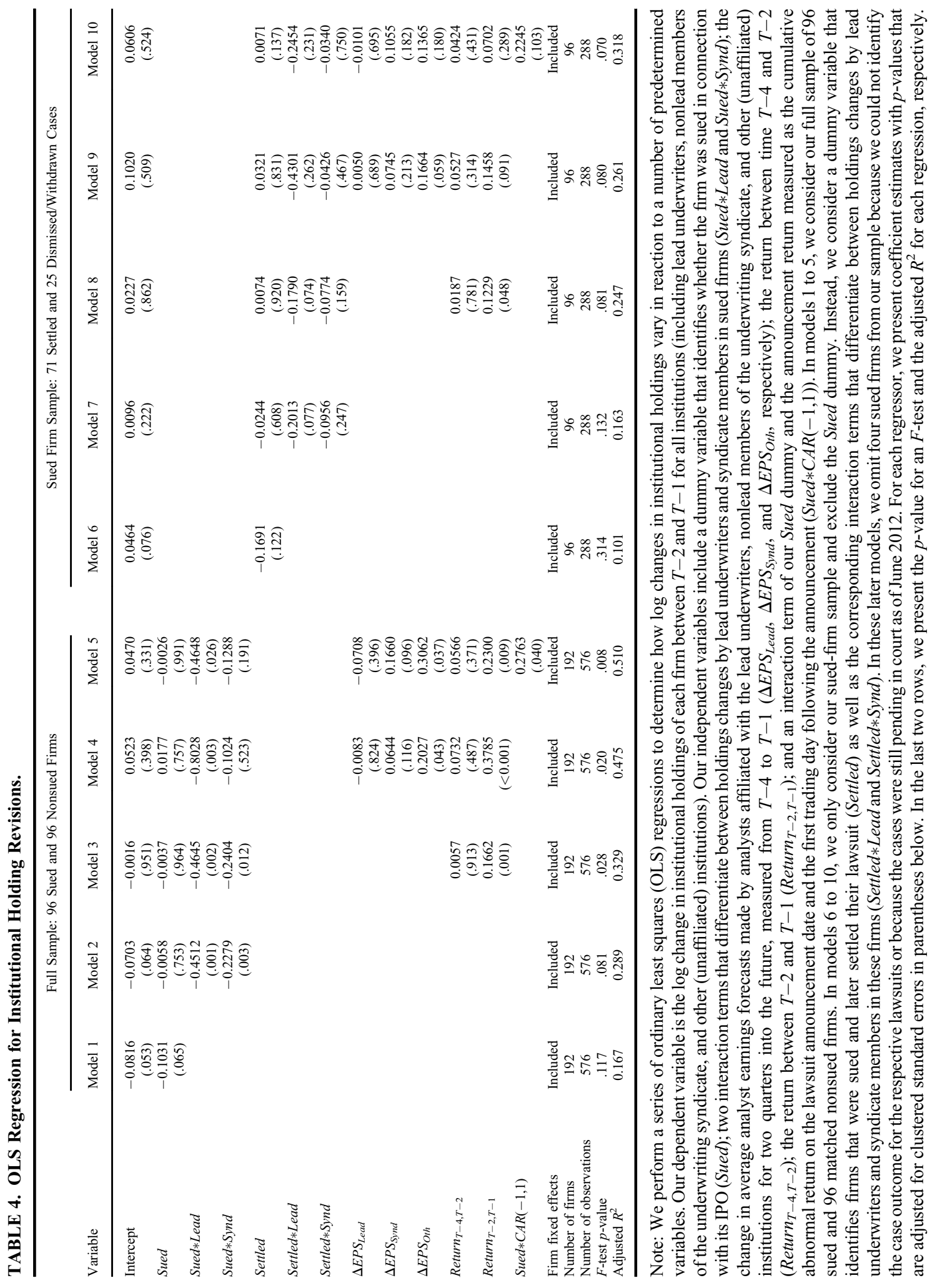


members of the underwriting syndicate) are comparatively poor predictors of institutional trading activity, whereas revisions in earnings forecasts by unaffiliated analysts exert a much higher (and more significant) influence on institutional trading.

As expected, we find that during the period $T-2$ to $T-1$, institutional holdings changes and abnormal returns move in the same direction. Finally, we observe that institutions appear to correctly avoid sued IPOs with a large negative surprise component of the announcement as measured by our interactive variable $\operatorname{Sued} * C A R(-1,1){ }^{23,24}$

Our results for models 6 to 10 in which we only consider our sued-firm sample and explore the ability of institutions to differentiate between settled and dismissed or withdrawn lawsuits provide some indication that lead underwriters are better able than other institutions in anticipating merited cases that eventually become settled. The respective interaction term (Settled $*$ Lead) is only weakly significant in models 7 to 8 , however, and loses its significance when we include additional explanatory variables in our regressions. The coefficients for the other variables in models 6 to 10 are largely in line with what we found in models 1 to 5 , although their significance tends to be smaller. Last, we added firm fixed effects to control for any firm-specific effects and apply clustering-adjusted standard errors at the firm level. Overall, the results are not sensitive to these changes and our conclusions remain intact. ${ }^{25}$ That is, the results in Tables 3 and 4 support Hypothesis 1 that suggests that lead underwriters have superior information about firms they took public and reduce their holdings in eventual litigation targets before the companies' stock price decline.

\section{Regression of CARs on Holdings Changes}

To provide further support for our findings that suggest that lead underwriters have an information advantage over other institutional investors, we examine firm stock returns conditional on lead underwriter selling; that is, we explore how stock returns around the litigation date (i.e., during a $(-1,1)$ event window) relate to the prelitigation holdings changes by our three institutional subgroups. To assess the relative contribution of each group's holdings changes to our empirical findings, we provide regression results for three models in which the respective variables are added consecutively. Our results are reported in Table 5.

As expected, we find a significant positive and higher magnitude coefficient for our variable that measures holdings changes by lead underwriters (with the associated $p$-values in models 1 to 3 of Table 5 ranging from .022 to .062), whereas the coefficients for holdings changes by the two other types of institutions are smaller and insignificant. In addition to the univariate results presented in Table 3, this result supports Hypothesis 2 and suggests that lead underwriters, but not nonlead underwriters and unaffiliated institutions, are able to

\footnotetext{
${ }^{23}$ Unreported tests in which we regress institutional holdings changes separately for each type of institution suggest that the coefficient estimates for our $\operatorname{Sued} * C A R(-1,1)$ interaction term are notably less significant for nonlead underwriters than for lead underwriters and are largely insignificant for unaffiliated institutions, indicating that lead (and to a lesser extent nonlead) underwriters are better than unaffiliated institutions in avoiding sued IPOs with a large negative surprise component of the announcement.

${ }^{24} \mathrm{We}$ also perform tests in which we employ a variable that measures the announcement return during longer term event windows, including a variable specification that captures the return during the entire litigation quarter (irrespective of when during that quarter the firm was sued). Our results are similar when we use those variable definitions instead.

${ }^{25}$ For the sake of brevity, these results are not reported here but are available upon request.
} 
TABLE 5. Regression of $C A R(-1,1)$ on Holdings Changes by Different Types of Institutions.

\begin{tabular}{lccc}
\hline Variable & Model 1 & Model 2 & Model 3 \\
\hline Intercept & 0.1025 & 0.1153 & 0.2311 \\
& $(.001)$ & $(.534)$ & $(.363)$ \\
$\Delta$ Holdings $_{\text {Lead, } T-4, T-1}$ & 0.6857 & 0.9494 & 0.7984 \\
& $(.073)$ & $(.061)$ & $(.017)$ \\
$\Delta$ Holdings $_{\text {Synd, } T-4, T-1}$ & & 0.1976 & 0.1786 \\
& & $.480)$ & $(.536)$ \\
$\Delta$ Holdings $_{\text {Oth, } T-4, T-1}$ & & & 0.7143 \\
& Included & Included & $(.286)$ \\
Firm fixed effects & 96 & 96 & Included \\
Number of firms & 96 & 96 & 96 \\
Number of observations & .058 & .047 & 96 \\
F-test $(p$-value) & 0.369 & 0.342 & .025 \\
Adjusted $R^{2}$ & & 0.421 \\
\hline
\end{tabular}

Note: We report results for a series of ordinary least squares (OLS) estimations in which we regress the cumulative abnormal returns (CARs) during a $(-1,1)$ event window surrounding the litigation date (day 0 ) against the cumulative holdings changes by different types of institutions. Institutions are categorized as lead underwriters (Lead), nonlead syndicate members (Synd), and unaffiliated institutions (Oth). The cumulative holdings change for each institution $\left(\Delta\right.$ Holdings $\left._{\text {Lead }, T-4, T-1}\right)$ is calculated as the log change in the institution's holdings at time $T-1$ relative to its holdings at time $T-4$. Our sample consists of 96 firms that went public between January 1990 and December 2003 and were the target of an IPO-related securities class action lawsuit filed within one and three years after the issue date under Section 11 of the 1933 Securities Act. In each of these IPOs, at least one member of the underwriting syndicate reported holdings to the Securities and Exchange Commission on Form 13F. We calculate a firm's CAR following a market model approach. The firm's beta is proxied for by the average beta of all firms in the same industry (all firms with the same three-digit Standard Industrial Classification code), calculated over a threeyear period ending four quarters before the lawsuit announcement. Market returns are calculated based on the Center for Research in Security Prices NYSE/AMEX/NASDAQ value-weighted market index. For each regressor, we present coefficient estimates with $p$-values that are adjusted for clustered standard errors in parentheses below. In the last two rows we report results for an $F$-test as well as the adjusted $R^{2}$ for each regression, respectively.

predict lawsuits that hit the market by surprise (as indicated by a large negative $C A R(-1,1)$ ) and are thus able to change their stock holdings before the lawsuit announcement in the same direction as the CARs of sued firms around the litigation date.

\section{Changes in Analyst Opinions around Securities Class Action Announcements}

Our results suggest that lead underwriters in particular possess an information advantage over other market participants in new public companies. In this section, we aim to examine whether the differences in the trading behavior we documented for our three institutional groups are also reflected in concurrent earnings forecasts made by the institutions' sell-side analysts.

Specifically, from an analytical standpoint, we aim to explore whether there are any discernible differences in the earnings forecasts made by analysts affiliated with the lead underwriter, nonlead syndicate members, and unaffiliated institutions and to what extent their forecasts correspond to the trading behavior of their respective institutions.

The academic literature provides some evidence of a relation between the investment banking function of a firm and its sell-side analyst recommendations. 
Michaely and Womack (1999) document a significant bias by underwriter analysts and show that the bias is not fully recognized by the market. Dunbar, Hwang, and Shastri (1999) show that although initial buy recommendations by underwriters are uninformative, their subsequent recommendations trigger a stronger reaction in the market as even in the aftermarket underwriters are perceived to be well informed. Adams (2003), however, provides evidence that the coverage by analysts who are not affiliated with any members of the underwriting syndicate starts later and is more informative for investors than the coverage by analysts who were involved in the IPO. Our resultsdiscussed in the remainder of this section-largely support this later view. ${ }^{26}$ The extant literature has shown that an increase in the dispersion of analyst forecasts is associated with an increased probability of litigation (see, e.g., McTier and Wald 2011).

\section{Changes in Earnings Forecasts by Type of Institution}

We compare EPS forecasts for our sued and nonsued subsamples based on analyst data stratified into the three institutional groups. For consistency, we follow a similar reporting style as that in Table 3. In Panel A of Table 6, we report information on the average initial earnings per share (EPS) forecasts made for our sued and nonsued subsamples at time $T-4$ (measured in US $\varnothing$ ). Panel B considers mean changes in EPS forecasts during consecutive periods, and Panel C provides cumulative mean changes in relation to time $T-1$ and $T$. Concurrent trends in median EPS forecasts are largely similar and are omitted here for brevity. ${ }^{27}$ All EPS forecast changes in Panels B and C are calculated as $\triangle E P S_{t,}$, ${ }_{t-x}=\left(E P S_{t}-E P S_{t-x}\right) / P_{t}$, where $t=T-3$ to $T+3$ and $x=1$ to 3 ; that is, they represent the change in EPS forecasts from time $t-x$ to $t$ (measured in US $\phi$ ), scaled by the firm's stock price at time $t .^{28,29}$ When individual brokerage forecasts change during a quarter, we calculate a time-weighted average for that analyst.

The results in Panel A of Table 6 suggest that from a static perspective (i.e., with respect to their EPS forecast levels at time $T-4)$, lead-underwriter-affiliated analysts are

\footnotetext{
${ }^{26}$ See also James and Karceski (2006) who find similar biases by underwriter-affiliated analysts.

${ }^{27}$ In addition, we also explored contemporaneous trends in mean and median analyst recommendations. Our results are generally weaker when considering recommendation changes and are thus omitted here.

${ }^{28}$ Note that if a firm receives no analyst coverage in two consecutive quarters, we retain the firm in our data set but assign a zero change to the respective variables over that period. If an analyst initiates coverage for a firm for the first time or if his or her coverage ceases during a given quarter, we exclude that analyst from our calculations during that quarter. We also considered alternative approaches such as using log changes (as we did for institutional holdings). Our results are qualitatively unaffected when we use other computational approaches. Further note that because of initiations and terminations in analyst coverage by individual institutions and differences in the stock prices by which we scale the changes in EPS forecasts, the cumulative changes reported in Panel C of Table 6 do not always correspond to the quarterly changes reported in Panel B.

${ }^{29}$ Note that not all firms in our sample received parallel coverage by analysts affiliated with each of our three institutional subgroups. Although it would be preferable to limit our analysis in Table 6 to sued firms and matching nonsued firms that were each covered by at least one analyst from each institutional subgroup, this requirement would exclude too many (particularly smaller) firms from our sample. Consequently, our results in Table 5 should be interpreted with some caution as the calculations that underlie the mean changes in earnings forecasts by the three different types of analysts are subject to some variations in the number of firms they are effectively based on. As such, our results provide at best an indication of changes in earnings forecasts by different analysts over time but no exact firm-to-firm comparison. Future research that explores trends in analyst opinions in a non-IPO context should be able to provide additional insights in this area.
} 


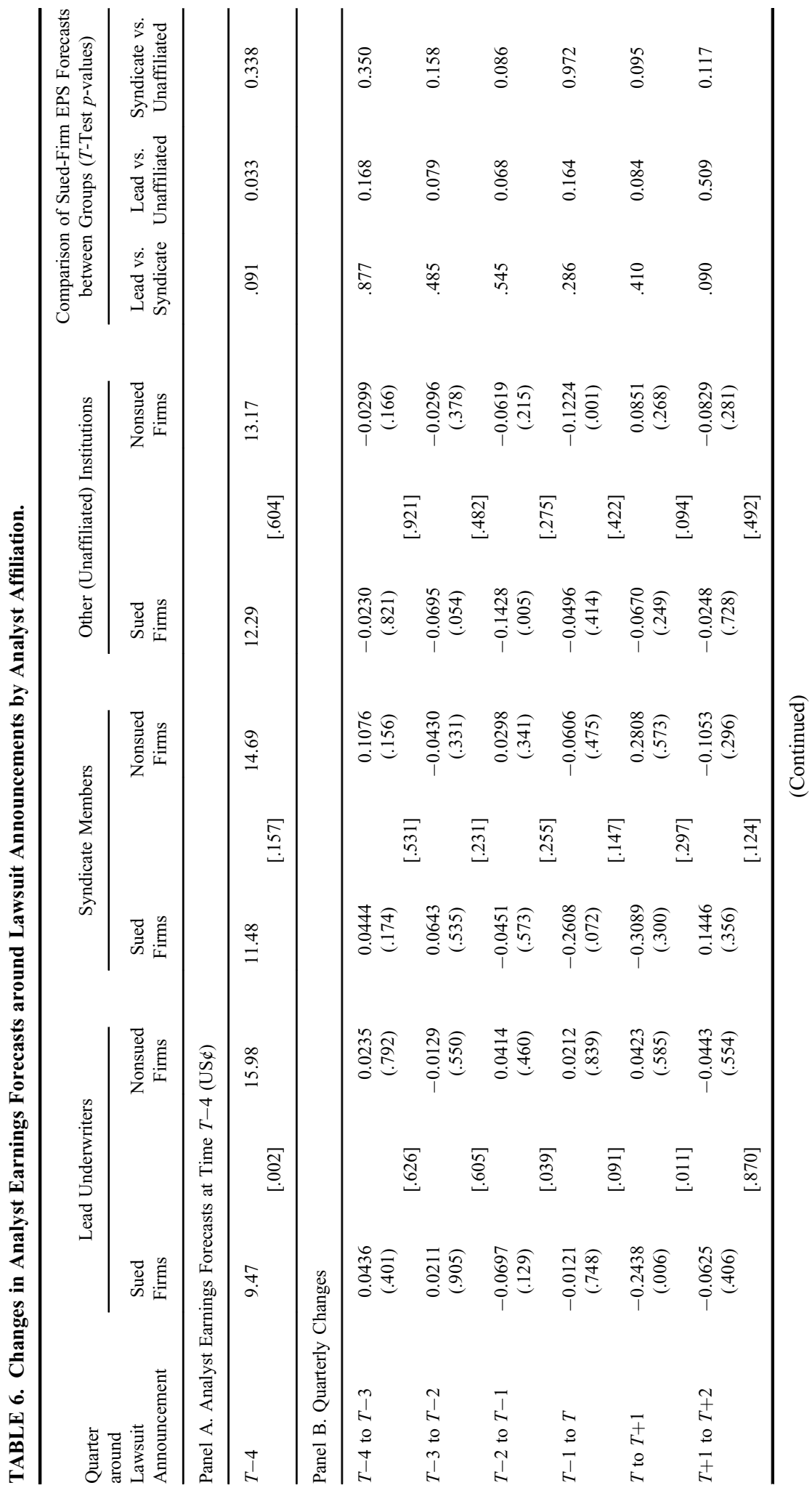




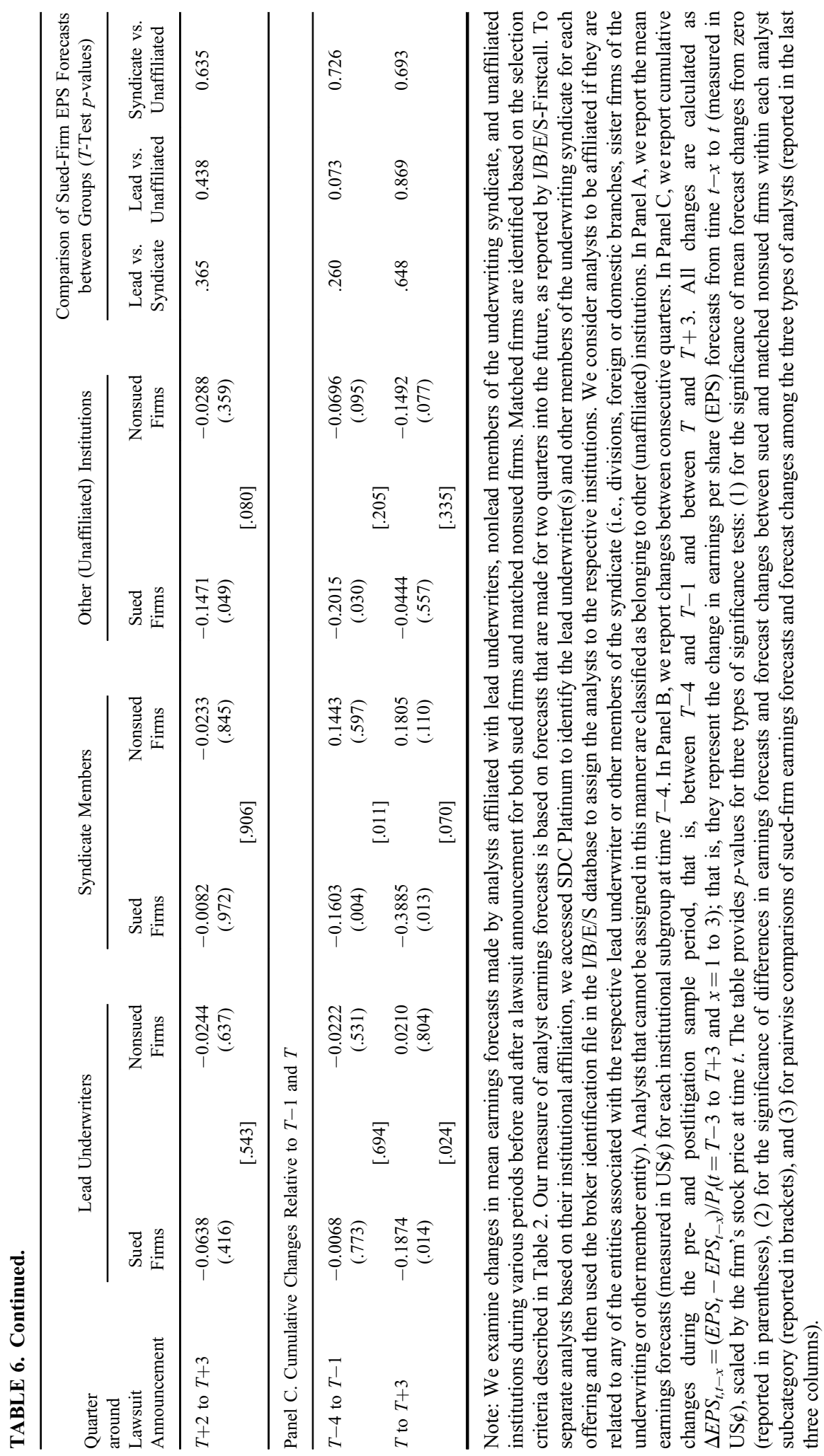


much more capable in discerning between potential litigation targets and nonsued firms than their counterparts in nonlead underwriting and unaffiliated institutions. Although lead analyst EPS forecasts for sued firms, for example, average only about 9.5 cents, they are significantly higher (at approximately 16 cents) for nonsued firms ( $p$-value of differences $=.002$ ). In contrast, the EPS forecasts made by analysts affiliated with nonlead underwriters and unaffiliated institutions tend to differ considerably less between sued and nonsued firms and fall closer to a grand sample average that lies at approximately 12 to 13 cents in our sample. This is confirmed by the last three columns in Panel A, where we test for the significance of differences in the EPS forecasts for sued firms made by the three different types of analysts. Here, the differences between lead analyst and nonlead analyst forecasts as well as between lead analyst and unaffiliated analyst forecasts are significant at the $10 \%$ and $5 \%$ levels, respectively.

From a dynamic perspective, that is, when considering changes in analyst opinions over time, our results in Panel B and C of Table 6 suggest that lead analysts make significant downward revisions in their earnings forecasts for sued firms relative to nonsued firms shortly before the litigation announcement ( $p$-value of differences $=.039$ during period $T-2$ to $T-1$ ). At the same time, however, unaffiliated analysts exhibit larger and much more significant downside revisions in their earnings forecasts for sued firms than do the other two groups of analysts. The decrease in average earnings forecasts for sued IPOs by unaffiliated analysts is significant when considering quarterly changes from $T-3$ to $T-2$ and from $T-2$ to $T-1$ or cumulative changes from $T-4$ to $T-1$. For syndicate members the results are significantly weaker, with only the cumulative changes being significantly different from zero. In the last three columns of Table 6 , we further test for the significance of differences in earnings forecasts among analysts affiliated with the three groups of institutions. Our results support Hypothesis 3 and confirm that before the litigation quarter, unaffiliated analysts make significantly larger downward revisions in their earnings forecasts than both lead and nonlead underwriter affiliated analysts. The aggressive downgrading by unaffiliated analysts combined with the comparatively small EPS forecast revisions made by lead-underwriter-affiliated analysts is different from the large decrease in lead underwriter holdings and the much smaller decrease in unaffiliated institutional holdings we observed before litigation announcements, but is consistent with the positive bias in underwriter recommendations documented by Michaely and Womack (1999) and Adams (2003). ${ }^{30,31}$

All groups of analysts continue to revise their expectations downward after the litigation date. Although the forecasts by analysts affiliated with lead and nonlead members of the underwriting syndicate remained largely constant in the prelitigation

\footnotetext{
${ }^{30}$ In fact, a similar upward bias can be observed when examining firms in our matched nonsued sample. Although they have experienced similar stock price declines as sued firms, lead underwriters tend to maintain comparatively high earnings forecasts for these firms before the litigation quarter whereas earnings forecasts by unaffiliated analysts show a steady decrease.

${ }^{31}$ Another possible explanation for the comparatively small revisions in earnings forecasts by lead analysts may be that they provided slightly lower EPS forecasts at time $T-4$ (see our results in Panel A of Table 6), that is, that they warned investors about possible problems the firm may be experiencing early on. However, this does not explain the discrepancy between the changes in EPS forecasts and holdings (which also started out at a significantly lower level at $T-4)$.
} 
period, they now exhibit a greater decline relative to the forecasts made by unaffiliated analysts. Again, this is not consistent with the behavior of affiliated money managers who start to reacquire shares in sued companies soon after the litigation date.

All of our results suggest that sued firms undergo a period of significant uncertainty before a lawsuit announcement. The fact that earnings forecasts differ increasingly before the litigation date suggests that analysts are more and more in disagreement about the future profitability of the firm as the lawsuit draws closer.

Although we are unable to discern at this point whether analysts react to problems that the firm is experiencing (which ultimately cause it to be sued) or whether they foresee the actual lawsuit filing, our results clearly indicate a decrease in analyst earnings forecasts before the litigation date. Moreover, our results suggest that although some analysts may be able to foresee or react to negative developments within sued firms, they fail to exhibit the same level of prudence as demonstrated by institutional money managers and underwriters in particular who are much more proactive in their actions than their in-house analysts.

\section{Robustness Tests}

To ensure that our results are not sensitive to changes in sample construction or methodology we perform a plethora of robustness tests. We are primarily concerned about the robustness of our results presented in Tables 3 and 6, that is, whether underwriters possess an information advantage over other institutional investors.

Drawing conclusions from a sample that combines daily data on IPOs and IPO lawsuits with quarterly institutional holdings is not straightforward. Institutions are not required to disclose the trades they make during a quarter; thus, we have to rely on end-ofquarter data to estimate changes in institutional ownership over time. A resulting measurement problem is illustrated by the following example: consider a lawsuit against an IPO firm that was filed at the beginning of the third quarter, say July 5. Consistent with our hypothesis, we expect institutional holdings at the end of the second quarter, that is, June 30 , to be significantly smaller than at the end of the first quarter due to institutional sales during the second quarter before the lawsuit announcement.

In contrast, consider a lawsuit that was filed September 20. Because the lawsuit is announced close to the end of the third quarter, it is likely that we will observe a much smaller change in institutional positions between the first and second quarters. Because in this case there are more than 80 days before the lawsuit announcement during which institutions may have sold part of their holdings, we expect changes in institutional holdings during the prior quarters to be less significant. Rather, we expect that changes in institutional holdings are largely reflected at the end of a quarter for lawsuits filed late during that quarter, and even then they may reflect sales or purchases that occurred shortly after the lawsuit announcement, making their interpretation difficult.

To control for these measurement problems, we perform a robustness test in which we break down each quarter into three one-month periods. Similar to Reuter (2006), we form three subsamples of our data set that contain lawsuits filed during the first, second, and third months of each quarter, respectively, and then re-perform our 
analysis for each subsample. We consistently find that our results are stronger and more significant for lawsuits filed during the first month of each quarter, that is, January, April, July, and October, and they are slightly less significant when we consider lawsuits filed in the last month of each quarter, that is, March, June, September, and December.

Our second robustness test examines whether our results are robust to variations in the selection criteria for lawsuits. We find no significant changes in our results when we include non-Section 11 lawsuits in our analysis or when we reduce the period we allow for a lawsuit to occur from three to two years. Our results are not robust to the inclusion of laddering cases, but given that these cases are inherently different in nature and primarily address the underwriter rather than the issuing firm, it is not surprising that they weaken our results. In addition, to ensure that our results are robust across different periods, we perform a robustness test in which we divide our IPO sample into two halves, that is, January 1990 to December 1996 and January 1997 to December 2003, and test whether we have similar findings in each subperiod. Our findings are little affected as our results are qualitatively and quantitatively consistent with the results for the full sample.

We then test whether our results are driven by differences in underwriter characteristics between sued and nonsued firms. As an additional matching criterion, we require that sued and matching nonsued firms must have been underwritten by an underwriter of similar reputation. We use the Carter and Manaster (1990), and Carter, Dark, and Singh (1998) underwriter rankings as revised by Jay Ritter ${ }^{32}$ to match sued and nonsued firms. Although this reduces our sample size by 10 firms for which we find no matching nonsued firm, our results are little affected.

In a final robustness test we address the link between stock prices and litigation likelihood. It is important to recognize that the relation between these two factors is not straightforward. On one hand, we expect stock prices to decline before a lawsuit announcement as informed investors reduce their positions in the litigation target to avoid the postannouncement stock price decline that most sued firms in our sample experience. On the other hand, we expect that stock price declines themselves increase a firm's likelihood of being sued. As Walker et al. (2012) argue, the larger the stock price decline, the larger the litigatable loss that plaintiffs can claim in a lawsuit. Given the endogenous relation between litigation risk and prelitigation stock price performance, it is difficult to discern to what degree informed investors can predict a lawsuit and to what degree they react to or anticipate stock price declines. We address these concerns through two robustness tests.

When examining institutional holdings at the end of the first quarter following the lockup expiration date for all IPOs during our sample period, we observe that lead underwriters retain an ownership stake of approximately $1.6 \%$ in firms that were subsequently sued, compared to $3.6 \%$ for firms that were not sued. Similarly, when examining lead underwriter holdings in firms that experienced market-adjusted price declines of over $20 \%$ within two quarters following the lockup expiration dateirrespective of whether the firms were eventually sued - we observe that underwriter

\footnotetext{
${ }^{32}$ See Jay Ritter's website at http://bear.cba.ufl.edu/ritter/Rank.htm for a complete list of underwriter rankings. If there is more than one lead underwriter, we calculate the average reputation of the lead underwriters. The data are also used in Loughran and Ritter (2004).
} 
stakes in the "losers" were only $2.5 \%$, compared to a $4.3 \%$ ownership stake in the "winners." The differences in means and medians for both of these tests are significant at the 5\% significance level. Similar, but less significant, differences can be observed for nonlead syndicate members and unaffiliated institutions.

These results suggest that underwriters can not only predict the likelihood of litigation, but can also predict the likelihood of share price declines that may attract litigation. In addition to observing significant reductions in the holdings by lead underwriters before lawsuit filings, we observe that shortly after the IPO lockup period they retain smaller positions in firms that experience significant price declines regardless of whether these firms are ultimately sued.

\section{Conclusions}

Institutional investors, through their monitoring of the firms they invest in, are often viewed as "smart money" investors. A large body of research has investigated differences in trading patterns among different types of institutions, that is, banks, mutual funds, and so on. To our knowledge, there have been no studies that compare the trading of underwriters and nonunderwriting institutions in young IPO firms, possibly because of a lack of specific event data around which such trading behavior can be measured. We employ a unique data set of IPO-related securities class action cases that allows us to overcome this problem. By examining trading patterns by lead underwriters, nonlead members of the underwriting syndicate, and other (unaffiliated) institutions before these lawsuits, we are able to document that lead underwriters retain an information advantage in the firms they take public and are more proactive in reducing their positions in eventual litigation targets than other institutional investors. Nonlead members of the underwriting syndicate - although also involved in the IPO process - and unaffiliated institutions appear to be less proactive in avoiding sued IPOs. Our results are robust to variations in our sample selection and to methodological changes.

We further explore trends in analyst opinions around securities class action announcements. Specifically, we investigate whether lawsuits are preceded by negative revisions in analyst earnings forecasts (measured separately for each of our three groups of institutions) and whether these revisions correspond to the holdings changes within the respective institutional subgroups. Our findings suggest that litigation announcements are preceded by a significant deterioration of unaffiliated analyst opinions about the respective firm. At the same time, however, we document a considerable reluctance by lead-underwriter-affiliated analysts to lower their earnings forecasts before the litigation announcement - a pattern that stands in stark contrast to their institutions' otherwise more informed trading behavior. Finally, we find evidence suggesting that lead underwriters (and to a lesser extent other institutions) trade back into some firms after they have been sued and that they are able to identify postlitigation winners, that is, firms that recover well from the lawsuit and the generally associated stock price declines.

From a practical standpoint, our findings allow investors to better understand the rationale behind patterns in institutional trading and analyst opinions and the potential implications these patterns may have on their portfolio. In particular, a substantial 
decrease in analyst opinions and large institutional holdings revisions in the first few years after an IPO provide investors with a possible warning sign that a firm may get sued.

The results of this study call for more transparency and disclosure. We believe that regulators and policy makers should consider requiring more frequent trade and position disclosures, particularly so from underwriters and affiliated institutions. Given that we document well-informed trading behavior by these institutions despite the fact that we only had access to data on long positions (which the institutions have to disclose to the SEC on Form $13 \mathrm{~F}$ ) but not on short positions, warrants, or daily trades, suggests that our findings may be even stronger (and institutional behavior even more abusive) than what we documented here. Large financial institutions have been increasingly active on the short side of trades and may even exploit their information advantages without reporting any changes in their long positions on Form 13F. A mandatory disclosure of all equity-related trades including short sales and derivatives would help promote openness and fairness in the contemporary marketplace and would reduce the financially exploitable information advantage that well-informed institutions have over other market participants.

\section{References}

Adams, B., 2003, When they say it does matter: A study of analyst coverage of initial public offerings, Unpublished dissertation, Arizona State University.

Aggarwal, R., 2000, Stabilization activities by underwriters after initial public offerings, Journal of Finance 55, 1075-1104.

Aggarwal, R., N. Prabhala, and M. Puri, 2002, Institutional allocation in initial public offerings: Empirical evidence, Journal of Finance 57, 1421-42.

Alexander, J., 1991, Do the merits matter? A study of settlements in securities class actions, Stanford Law Review 43, 498-598.

Antunovich, P., and A. Sarkar, 2006, Fifteen minutes of fame? The market impact of Internet stock picks, Journal of Business 79, 3209-51.

Bajaj, M., S. Mazumdar, and A. Sarin, 2003, Securities class action settlements: An empirical analysis, Santa Clara Law Review 43, 1001-33.

Barabanov, S., and M. McNamara, 2013, On the market perception of information asymmetry: Concentration of ownership by different types of institutions and the bid-ask spread, Working Paper, University of St. Thomas and Washington State University.

Barabanov, S., O. Ozocak, H. Turtle, and T. Walker, 2008, Institutional investors and shareholder litigation, Financial Management 37, 227-50.

Barber, B., and J. Lyon, 1996, Detecting abnormal operating performance: The empirical power and specification of test statistics, Journal of Financial Economics 41, 359-99.

Bennett, J., R. Sias, and L. Starks, 2003, Greener pastures and the impact of dynamic institutional preferences, Review of Financial Studies 16, 1203-38.

Binay, M., V. Gatchev, and C. Pirinsky, 2007, The role of underwriter-investor relationships in the IPO process, Journal of Financial and Quantitative Analysis 42, 785-809.

Breeden, D., M. Gibbons, and R. Litzenberger, 1989, Empirical tests of the consumption-oriented CAPM, Journal of Finance 44, 231-65.

Brunnermeier, M., and L. Pedersen, 2005, Predatory trading, Journal of Finance 60, 1825-63.

Butler, A., 2008, Distance still matters: Evidence from municipal bond underwriting, Review of Financial Studies 21, 763-84.

Carter, R., F. Dark, and A. Singh, 1998, Underwriter reputation, initial returns and long run performance of IPO stocks, Journal of Finance 53, 285-311.

Carter, R., and S. Manaster, 1990, Initial public offerings and underwriter reputation, Journal of Finance 45, $1045-67$.

Chaghouri, M., and T. Walker, 2005, On the dynamics of securities class action litigation, Working Paper, Concordia University. 
Chen, H., and J. Ritter, 2000, The seven percent solution, Journal of Finance 55, 1105-32.

Cliff, M., and D. Denis, 2004, Do IPO firms purchase analyst coverage with underpricing? Journal of Finance 59 , 2871-2901.

Corwin, S., and P. Schultz, 2005, The role of IPO underwriting syndicates: Pricing, information production, and underwriter competition, Journal of Finance 60, 443-86.

Dechow, P., A. Hutton, and R. Sloan, 2000, The relation between analyst forecasts of long-term earnings growth and stock price performance following equity offerings, Contemporary Accounting Research 17, 1-32.

Dunbar, C., C. Hwang, and K. Shastri, 1999, Underwriter analyst recommendations: Conflict of interest or rush to judgment? Working Paper, University of Western Ontario, Hong Kong University of Science \& Technology, and University of Pittsburgh.

Ellis, K., R. Michaely, and M. O'Hara, 2000, When the underwriter is the market maker: An examination of trading in the IPO aftermarket, Journal of Finance 55, 1039-74.

Field, L., and M. Lowry, 2004, How is institutional investment in initial public offerings related to the long-run performance of these firms? Working Paper, Pennsylvania State University.

Fishe, R., 2002, How stock flippers affect IPO pricing and stabilization, Journal of Financial and Quantitative Analysis 37, 319-40.

Gande, A., and C. Lewis, 2009, Shareholder initiated class action lawsuits: Shareholder wealth effects and industry spillovers, Journal of Financial and Quantitative Analysis 44, 823-50.

Gompers, P., and A. Metrick, 2001, Institutional investors and equity prices, Quarterly Journal of Economics 116 , 229-59.

Griffin, P., J. Grundfest, and M. Perino, 2004, Stock price response to news of securities fraud, Abacus 40, 21-48.

Grinblatt, M., S. Titman, and R. Wermers, 1995, Momentum investment strategies, portfolio performance, and herding: A study of mutual fund behavior, American Economic Review 85, 1088-1105.

Hao, Q., 2007, Laddering in initial public offerings, Journal of Financial Economics 85, 102-22.

Hegde, S., C. Malone, and J. Finnerty, 2003, The financial impact of fraud and securities class action suits, Working Paper, University of Connecticut, Massey University and Analysis Group/Economics.

Himmelberg, C. P., R. G. Hubbard, and D. Palia, 1999, Understanding the determinants of managerial ownership and the link between ownership and performance, Journal of Financial Economics 53, 353-84.

James, C., and J. Karceski, 2006, Strength of analyst coverage following IPOs, Journal of Financial Economics 82, 1-34.

Johnson, M., R. Kasznik, and K. Nelson, 2001, The impact of securities litigation reform on the disclosure of forward-looking information by high technology firms, Journal of Accounting Research 39, 297-327.

Jones, C., and S. Weingram, 1996, The determinants of 10b-5 litigation risk, Working Paper, Stanford University.

Jordan, B., M. Liu, and Q. Wu, 2012, Do investment banks listen to their own analysts? Journal of Banking and Finance 36, 1452-63.

Li, X., and R. Masulis, 2005, Pre-IPO investments by financial intermediaries: Certification or moral hazard? Working Paper, University of Miami and Vanderbilt University.

Loughran, T., and J. Ritter, 2004, Why has IPO underpricing changed over time? Financial Management 33, 5-37.

Lowry, M., and S. Shu, 2002, Litigation risk and IPO underpricing, Journal of Financial Economics 65, 309-36.

McTier, B., and J. Wald, 2011, The causes and consequences of securities class action litigation, Journal of Corporate Finance 17, 649-55.

Michaely, R., and K. Womack, 1999, Conflict of interest and the credibility of underwriter analyst recommendations, Review of Financial Studies 12, 653-86.

Nofsinger, J., and R. Sias, 1999, Herding and feedback trading by institutional and individual investors, Journal of Finance 54, 2263-95.

O’Brien, P., and R. Bhushan, 1990, Analyst following and institutional ownership, Journal of Accounting Research 28, 55-76.

Reuter, J., 2006, Are IPO allocations for sale? Evidence from mutual funds, Journal of Finance 61, $2289-2324$.

Rowley, T., and J. Baum, 2008, The dynamics of network positions and strategies, Advances in Strategic Management 25, 641-71.

Sias, R., L. Starks, and S. Titman, 2006, Changes in institutional ownership and stock returns: Assessment and methodology, Journal of Business 79, 2869-2910.

Sibley, A., and E. Burch, 1979, Optimal selection of matched pairs from large data bases, Decision Sciences 10, 62-70.

Thakor, A., 2005, The unintended consequences of securities litigation, Working Paper, Washington University in St. Louis.

Walker, T., H. Turtle, K. Pukthuanthong, and D. Thiengtham, 2012, Legal opportunism, Working Paper, Concordia University.

Zhu, Y., 2009, The relation between IPO underpricing and litigation risk revisited: Changes between 1990 and 2002 , Financial Management 38, 323-55. 
